Our finding that MACs serve as a direct substrate for methanogens may not be limited to coal-bed environments. In the deep subsurface, MACs are contained in sedimentary organic matter derived from lignin in higher plants, namely kerogen, with quantitative variation depending on the maturity (24). In fact, alkyl-methoxyphenols with a short $\mathrm{C}_{1}-\mathrm{C}_{3}$ chain have been detected in the pyrolysates of immature kerogen extracted from a Cretaceous (Cenomanian) black shale (25). Kerogen is ubiquitous in sediments and accounts for most of the organic matter in subsurface environments (26). Microorganisms from the genus Methermicoccus and related clones have often been detected in deep subsurface environments worldwide (fig. S5). Methoxydotrophic methanogenesis may therefore play an important role in the biogeochemical carbon cycle in Earth as well as in the formation of biogenic gas, which accounts for more than $20 \%$ of natural gas resources, including CBM (27).

\section{REFERENCES AND NOTES}

1. World Energy Outlook 2015 (International Energy Agency, 2015).

2. D. Strąpoć, M. Mastalerz, C. Eble, A. Schimmelmann, Org. Geochem. 38, 267-287 (2007).

3. T. Thielemann, B. Cramer, A. Schippers, Org. Geochem. 35, 1537-1549 (2004).

4. D. Strąpoć et al., Annu. Rev. Earth Planet. Sci. 39, 617-656 (2011).

5. S. Shimizu et al., Geobiology 5, 423-433 (2007).

6. M. S. Green, K. C. Flanegan, P. C. Gilcrease, Int. J. Coal Geol. 76. 34-45 (2008)

7. S. H. Harris, R. L. Smith, C. E. Barker, Int. J. Coal Geol. 76 , 46-51 (2008).

8. M. Krüger et al., Geomicrobiol. J. 25, 315-321 (2008).

9. T. J. Penner, J. M. Foght, K. Budwill, Int. J. Coal Geol. 82, 81-93 (2010).

10. F. Inagaki et al., Science 349, 420-424 (2015).

11. D. Ritter et al., Int. J. Coal Geol. 146, 28-41 (2015).

12. D. W. van Krevelen, Coal: Typology, Chemistry, Physics, Constitution (Elsevier, 1993).

13. M. Vandenbroucke, C. Largeau, Org. Geochem. 38, 719-833 (2007).

14. S. A. Stout, J. J. Boon, W. Spackman, Geochim. Cosmochim. Acta 52, 405-414 (1988)

15. H. A. Stafford, Phytochemistry 27, 1-6 (1988).

16. P. G. Hatcher, D. J. Clifford, Org. Geochem. 27, 251-274 (1997).

17. E. J. P. Jones et al., Int. J. Coal Geol. 76, 138-150 (2008).

18. H. Guo et al., Appl. Microbiol. Biotechnol. 96, 1587-1597 (2012).

19. D. Strąpoć, M. Ashby, L. Wood, R. Levinson, B. Huizinga, in Applied Microbiology and Molecular Biology in Oilfield Systems, C. Whitby, T. Skovhus, Eds. (Springer, 2010), chap. 25.

20. R. K. Thauer, A.-K. Kaster, H. Seedorf, W. Buckel, R. Hedderich, Nat. Rev. Microbiol. 6, 579-591 (2008)

21. L. Cheng et al., Int. J. Syst. Evol. Microbiol. 57, 2964-2969 (2007).

22. E. Pierce et al., Environ. Microbiol. 10, 2550-2573 (2008).

23. S. W. Ragsdale, E. Pierce, Biochim. Biophys. Acta 1784 , 1873-1898 (2008).

24. J. W. De Leeuw, C. Largeau, in Organic Geochemistry, M. H. Engel, S. A. Macko, Eds. (Plenum, 1993), chap. 2.

25. V. Salmon et al., Org. Geochem. 27, 423-438 (1997).

26. B. Durand, Kerogen, Insoluble Organic Matter from Sedimentary Rocks (Editions Technip, 1980), chap. 1.

27. B. J. Katz, Open Geol. J. 5, 75-83 (2011).

\section{ACKNOWLEDGMENTS}

We thank Japan Petroleum Exploration Co., Ltd. (JAPEX)

for providing samples from an oil reservoir; F. Nozawa, K. Shuin,

Y. Shinotsuka, T. Ujiie, and X. Meng for technical support; and M. Nobu for valuable comments. Supported by JSPS KAKENHI grants JP26709070, JP25289333, JP26710012, and JP26106004. M. shengliensis strain AmaM has been deposited as accession number NBRC 112467 in the Biological Resource Center, National Institute of Technology and Evaluation (NBRC). Genomic data of $M$. shengliensis strain AmaM are available in the Integrated Microbial Genomes system of the U.S. Department of Energy Joint Genome Institute with ID no. 2516653088 (Gold Project ID: Gp0021722)

\section{SUPPLEMENTARY MATERIALS}

www.sciencemag.org/content/354/6309/222/suppl/DC1

Materials and Methods

Figs. S1 to S5

Tables S1 and S2

References (28-32)

12 May 2016; accepted 29 August 2016

10.1126/science.aaf8821

\title{
GLOBAL CLIMATE CHANGE
}

\section{Impact ejecta at the Paleocene-Eocene boundary}

\author{
Morgan F. Schaller, ${ }^{1 *}$ Megan K. Fung, ${ }^{1}$ James D. Wright, ${ }^{2}$ \\ Miriam E. Katz, ${ }^{1}$ Dennis V. Kent ${ }^{2,3}$
}

Extraterrestrial impacts have left a substantial imprint on the climate and evolutionary history of Earth. A rapid carbon cycle perturbation and global warming event about 56 million years ago at the Paleocene-Eocene (P-E) boundary (the Paleocene-Eocene Thermal Maximum) was accompanied by rapid expansions of mammals and terrestrial plants and extinctions of deep-sea benthic organisms. Here, we report the discovery of silicate glass spherules in a discrete stratigraphic layer from three marine P-E boundary sections on the Atlantic margin. Distinct characteristics identify the spherules as microtektites and microkrystites, indicating that an extraterrestrial impact occurred during the carbon isotope excursion at the P-E boundary.

$\mathrm{E}$

jecta from known impact strewn fields have common features that provide useful criteria for identifying previously undiscovered impact ejecta in the geologic record. An ejecta deposit typically results from an air-fall event and occurs in a discrete stratigraphic layer. If spherules are present, they generally are glasses (microtektites) and may contain crystallites (microkrystites), both of which have characteristic morphologies and may be either solidified melt ejecta or vapor condensates (1-3). Microkrystites show distinct internal crystallite textures that indicate rapid quenching from high temperature and, if they formed as a vapor condensate, they can be enriched in projectile material (3). Microtektites that form as melt droplets solidify at slightly lower temperatures and are more likely to be vesicular; they may contain inclusions of high-temperature components such as lechatelierite, a quartz glass that solidifies above $1750^{\circ} \mathrm{C}(4,5)$. Shockmetamorphosed grains can be associated with microtektites but are not uniformly distributed throughout a strewn field. For example, the presence and abundance of shocked grains is spatially heterogeneous in the widespread Australasian strewn field [for which an impact crater has yet to be identified, despite being the largest and youngest Cenozoic tektite event at 0.8 million years ago (Ma)]. The Ivory Coast strewn field (next youngest

${ }^{1}$ Earth and Environmental Sciences, Rensselaer Polytechnic Institute (RPI), Troy, NY 12180, USA. Earth and Planetary Sciences, Rutgers University, Piscataway, NJ 08854, USA. ${ }^{3}$ Lamont-Doherty Earth Observatory (LDEO), Columbia University, Palisades, NY 10964, USA.

*Corresponding author. Email: schall@rpi.edu at 1.1 Ma) that emanated from Bosumtwi crater contains (micro)tektites but no shocked mineral grains [see (6) for review].

We examined three marine Paleocene-Eocene (P-E) boundary sections that encompass the onset of the carbon isotope excursion (CIE) that defines the P-E boundary (7) (Fig. 1): continental shelf sites Wilson Lake B $\left(39.6598^{\circ} \mathrm{N}, 75.0472 \mathrm{~W}^{\circ}\right)$ and Millville [Ocean Drilling Program (ODP) Leg $\left.174 \mathrm{AX} ; 39.4046^{\circ} \mathrm{N}, 75.0889^{\circ} \mathrm{W}\right](8)$, where the onset of the CIE coincides with the base of the thick Marlboro Clay unit of the Salisbury Embayment, and pelagic sediments at ODP Hole 1051B at Blake Nose $\left(30.0531^{\circ} \mathrm{N}, 76.3578^{\circ} \mathrm{W}\right.$, water depth $\left.1980.6 \mathrm{~m}\right)$ (9). To constrain the stratigraphic level of the CIE onset, we use detailed bulk sediment carbonate isotope records from Wilson Lake B and Millville (10) and Hole 1051B (11). We also report preliminary data from an exposure of the Marlboro Clay near Medford, New Jersey, to eliminate the possibility of spurious drilling-induced contamination as the source for the spherules [see (12)].

At the Wilson Lake B and Millville shelf localities, as well as Hole 1051B, peak spherule abundance occurs close to the P-E boundary as constrained by the $\delta^{13} \mathrm{C}$ decrease in bulk sediment (Fig. 1). Spherules are found over a $\sim 20$-cm interval in each case, with the number of spherules increasing sharply up-section from zero below to a peak at or close to the P-E boundary. Maximum abundances in the $>63-\mu \mathrm{m}$ size fraction are between 2.5 and 3 spherules per $g$ at Wilson Lake B and Millville and 4 spherules per $\mathrm{g}$ at Hole 1051B, followed by a gradual decline in abundance to zero over $\sim 10 \mathrm{~cm}$. At Wilson Lake B and Millville, the peak spherule abundance coincides with the 
basal contact of the Marlboro Clay, which is gradational with some reworking of the underlying Vincentown Formation facies.

These abundances are similar to impact spherule abundances in distal ejecta layers linked to other extraterrestrial impact events, such as the Late Eocene clinopyroxene (cpx)-bearing spherule layer associated with the Popigai impact crater (13-15). Late Eocene cpx spherules that are found in ODP Site 738 in the southern Indian Ocean [ 2 spherules per $\mathrm{g}(>150 \mu \mathrm{m})]$, in ODP Site 689 in the Southern Ocean ( 5 to 6 spherules per $g$ ( $>63 \mu \mathrm{m}$ ) [see (13) for review], and at Massignano, Italy $[\sim 4$ spherules per $\mathrm{g}(>150 \mu \mathrm{m})(16)]$ show concentrations similar to ours.

The glassy spherules from Wilson Lake B and Millville range from 65 to $500 \mu \mathrm{m}$ in diameter (average $302 \mu \mathrm{m}$ ), whereas those at Hole 1051B average $274 \mu \mathrm{m}$ in diameter. They have generally spherical and rotational morphologies, as well as other characteristics of splash-form microtektites (1, 17) (Fig. 2), and are occasionally colorless, translucent green, or dark-brown/black. The spherules often have surface pits (Fig. 2, A and C) and in some cases microcraters (Fig. 2G and fig. S7), indicating relative velocities high enough to fracture the spherules on impact with one another or other objects after solidification. Such microcraters would be an unexpected feature of volcanic spherules. There are also occasional dumbbell forms and smaller spherules accreted to larger ones (Fig. 2F), often of different chemical composition (Fig. 3E), suggesting that they were sintered to one another in a molten form and quenched rapidly. We conclude that the stratigraphic distribution and morphologies of the spherules are wholly consistent with the expected manifestation of an air-fall sedimentary event such as an impact ejecta bed, modified by minor and typical postdepositional bioturbation of marine sediments.

Major oxide chemistries of the P-E spherules show a wide range of compositions distributed equally among Wilson Lake B, Millville, and Hole 1051B (Fig. 4) (12). The spherules are $\sim 33$ to $\sim 50 \%$ $\mathrm{SiO}_{2}$ and have $\mathrm{CaO}$ contents between $\sim 20$ to $\sim 35 \%$, which is consistent with a $\mathrm{CaCO}_{3}$-rich target rock, with $\mathrm{Al}_{2} \mathrm{O}_{3}$ and $\mathrm{FeO}$ as the second and third most abundant oxides, at around $15 \%$ and $10 \%$ on average, respectively. This variability is typical of tektite strewn fields and consistent with an impact origin of the spherules $(18,19)$. Impact melts have little time for homogenization, but a population of major oxide chemistries will generally follow broadly linear compositional trends with $\mathrm{SiO}_{2}$ content because they were generated from the same source rock at the site of impact (18). In contrast, ashes or spherules from a volcanic eruption tend to exhibit inter- and intraspherule compositional homogeneity (19). Magma is generally well mixed during a single eruptive event, and hence volcanic spherules from the same eruptive sequence will be compositionally homogeneous and generally have much higher water content than impact spherules [up to a few weight \% (wt \%) (20)]. The water content of impact glasses is generally much lower than volcanic spherules $(21,22)$ because water is removed by vapor stripping during solidification (23). Field transmission infrared spectroscopy (FTIR) on representative P-E spherules reveals water contents below $0.023 \mathrm{wt} \%$ (see table S5), much lower than expected for volcanic spherules but typical of impact-generated microtektites.

In cross section, the internal texture of most of the P-E spherules is glassy and relatively featureless (Fig. 3); exceptions are the less common microkrystites (discussed below). The glassy spherules also occasionally have microlites just inside the rims and are mildly vesicular. This vesicular nature, and the composition discussed above, are inconsistent with iron or stony micrometeorites and other cosmic spherules, which are generally either chondritic or differentiated and do not show evidence of volatile degassing (24).

A key observation is the presence of amorphous, occasionally vesicular, nearly pure $\mathrm{SiO}_{2}$ glass (lechatelierite) inclusions within the microtektites (Fig. 3). Lechatelierite occurrence is confirmed by energy-dispersive x-ray spectroscopy (EDS) and micro-Raman spectroscopy in cross sections of spherules from Wilson Lake B, Millville, and Hole 1051B (see fig. S18). EDS was used to identify inclusions that are $>98 \% \mathrm{SiO}_{2}$, and Raman spectra from several of these are consistent with that of fulgurite (lightning-induced lechatelierite). Lechatelierite forms from melting of quartz and quenching to quartz glass, which generally occurs at temperatures $>1750^{\circ} \mathrm{C}(4,5)$. This indicates that the P-E spherules formed at temperatures at least this high, which excludes any known terrestrial volcanism as their origin. Melting of crustal silicates by impact sufficient to produce lechatelierite occurs at shock pressures of $\sim 30$ to $50 \mathrm{GPa}$
Fig. 1. Stratigraphic distribution of P-E spherules. (A to C) Stratigraphic distribution of P-E spherules from Millville (A), Wilson Lake B (B), and ODP Hole 1051B (C). Millville and Wilson Lake $B$ core depths are in drilling units (du) of decimal feet; core depth in Hole 1051B is in meters below seafloor (mbsf). The carbon isotope composition of bulk carbonate from Millville and Wilson Lake B is from Wright and Schaller (10), and Hole 1051B is from Katz et al. (11). (D) Map showing location of the New Jersey (NJ) margin locations, including exposure in Medford, NJ, compared to that of Site 1051, Blake Nose. At both Wilson Lake B and Millville, the spherules are found in the basal Marlboro Clay Formation. Because the CIE has not been defined stratigraphically at the equivalent exposure of the Marlboro Clay at Medford, the stratigraphic placement of the spherules recovered there is only qualitative with respect to the P-E boundary (12).
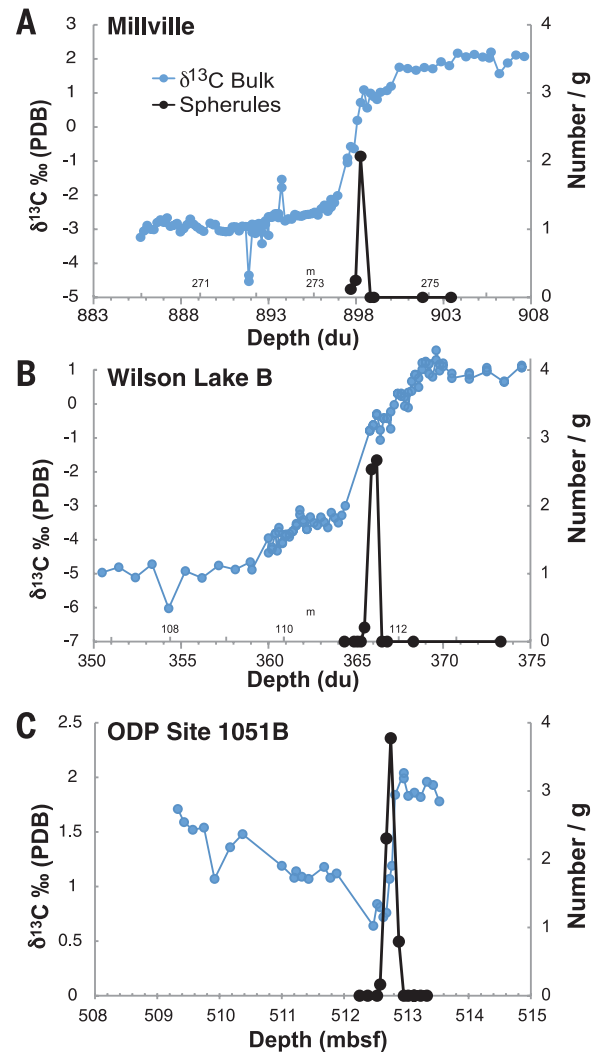

D

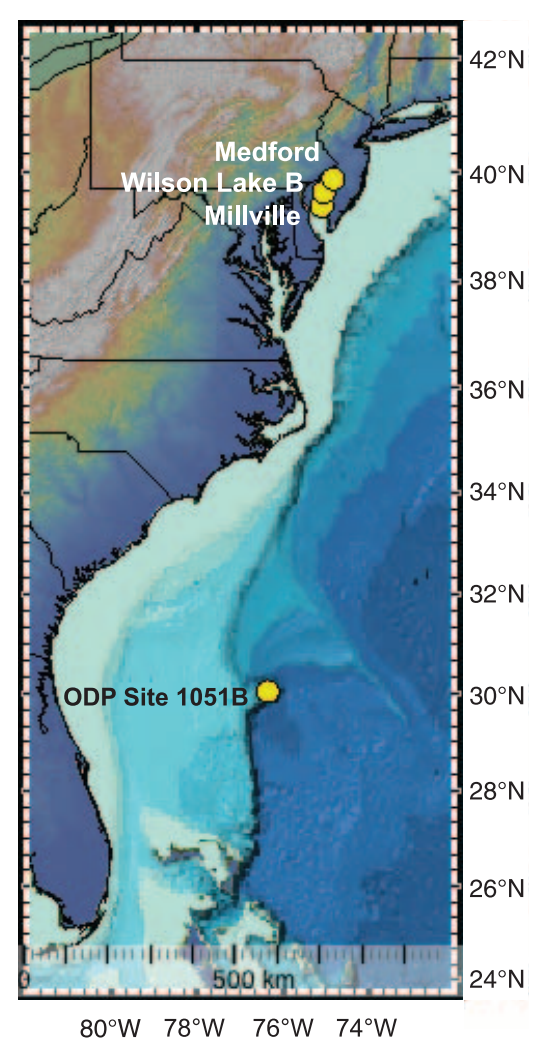


$(25,26)$. This observation implies that the target rock, although not necessarily silica-rich, at least had silt-sized or larger quartz grains that were melted on impact.

We have identified a quartz inclusion in a microtektite from Millville that has Raman spectral characteristics indicative of shocked quartz (Fig. 3D and fig. S21). In particular, the relaxation of the spectral peak corresponding to $\mathrm{SiO}_{2}$ bond-bending vibration from 464 to $460 \mathrm{~cm}^{-1}$ wave numbers observed in the Millville inclusion is consistent with observations from synthetic quartz experimentally shocked to peak pressures of $25.8 \mathrm{GPa}$ (27) (fig. S21) and is considered diagnostic. Other characteristic spectral shifts unique to shocked quartz also match the Millville grain. An extensive search for individual shocked quartz among the abundant shelf quartz grains will be the subject of future investigation.

A subset of spherules shows quench-crystallization textures of clinopyroxene (Raman spectra most closely matching augite or diopside; see fig. S20), in an otherwise glassy matrix (Fig. 3), typical of microkrystites $(3,28)$. The feathered, dendritic, and chainlike textures of the P-E microkrystites are classic rapid-crystallization high-temperature quench features of impact glasses with lower silica content from other strewn fields (12). Examples are clinopyroxene (cpx) microkrystites of the upper Eocene spherule layer (17, 29, 30), attributed to the Popigai impact event $(13,15,31)$, and the Cretaceous-Paleogene (K-Pg) spherules (also discussed below) (32). Among P-E microkrystites, vesicles are present but less common. Iron-rich inclusions are found in a few of the microkrystites and microtektites (fig. S16). These inclusions are generally noncrystalline and round or stringy. The presence of vesicles and lack of Ni-rich spinels in the P-E microkrystites are consistent with melt ejecta.

Within a given P-E spherule, the crystallite chemistry is close to the surrounding matrix glass. The distribution of major oxide chemistries is also similar to, but distinct from, the Late Eocene cpx spherules, which, like the P-E spherules, have high $\mathrm{CaO}$ contents (averaging only about $10 \mathrm{wt} \%$, which is substantially lower than the P-E spherules). However, unlike the P-E spherules, the Late Eocene spherules have compositions much higher in $\mathrm{SiO}_{2}$ and $\mathrm{Na}_{2} \mathrm{O}$, and lower in $\mathrm{Al}_{2} \mathrm{O}_{3}$ and $\mathrm{FeO}(18,30,33)$. The P-E microtektites and microkrystites are roughly equally represented at each of the three sites (Wilson Lake B, Millville, and Hole 1051B).

Impact ejecta, including spherules, are associated with the 66-Ma K-Pg boundary on the New Jersey coastal plain, such as in the Bass River core (34). For the following reasons, we find it implausible that the K-Pg spherules were reworked and redeposited at the P-E boundary. First, the chemistry of the P-E spherules differs significantly from those found at K-Pg boundary sections, with the latter being much higher in silica content (45 to 68\%) (35). Newly discovered deposits of unaltered microtektites and microkrystites at a K-Pg ejecta layer in Gorgonilla Island, Colombia (32), have much higher $\mathrm{SiO}_{2}$ and slightly lower $\mathrm{Al}_{2} \mathrm{O}_{3}$ than the $\mathrm{P}$-E spherules, and $\mathrm{Al}_{2} \mathrm{O}_{3}$ generally
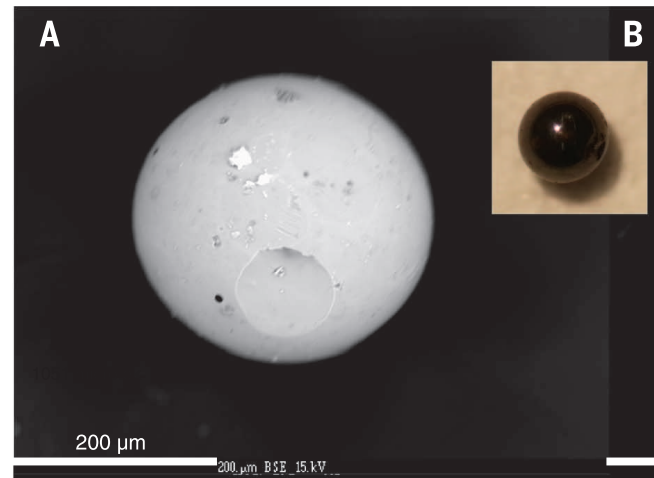

C
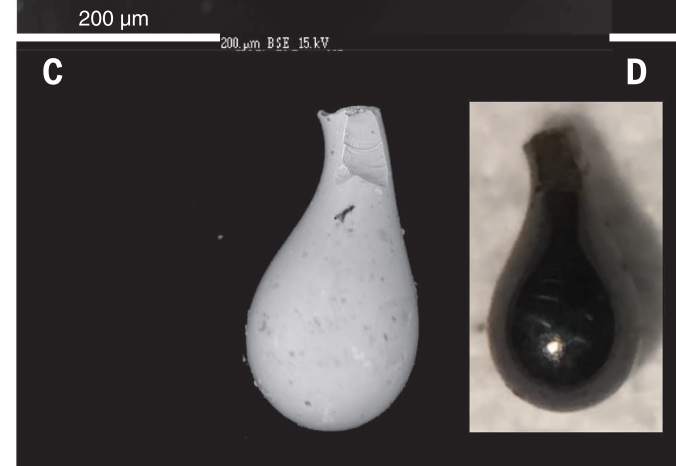

$00 \mu \mathrm{m}$
$500 \mu \mathrm{m}$

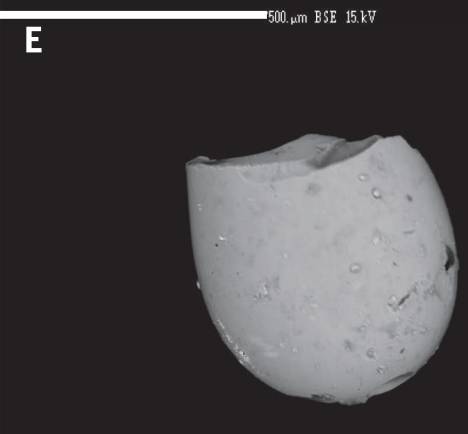

$200 \mu \mathrm{m}$

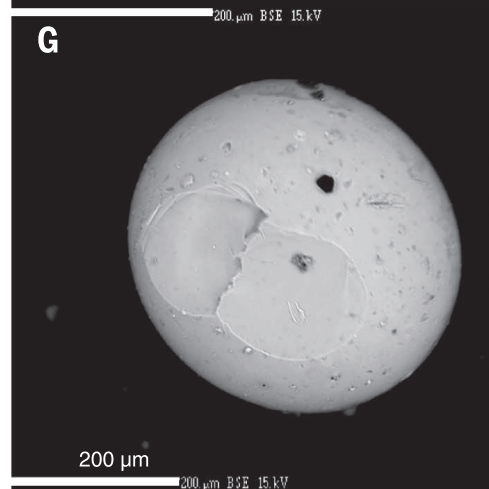

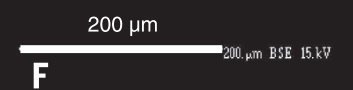

$\mathbf{F}$
Fig. 2. Electron backscatter (15 kV) images of representative P-E spherules from Hole 1051B, Wilson Lake B, and Millville cores and the Medford exposure. Selected color micrographs are shown as insets. (A) Microtektite with a surface pit from ODP Hole 1051B (512.75 mbsf). (B) Microkrystite from ODP Hole 1051B (512.75 mbsf). Round features on surface of microkrystite are vesicles and small accretionary material. (C) Teardrop-shaped glass spherule from Millville 898.8 drilling units (du); inset is photomicrograph of same object. (D) Microkrystite with surface pit (spallation or microcrater?) from Millville (898.8 du). Dark round surface features are exposed vesicles. (E) Broken drop-form or dumbbell from Wilson Lake B (366.2 du). (F) Microtektite from Wilson Lake B (365.9 du), with a smaller spherule accreted to the side. This nature of deformation is typical of accretion occurring in partially molten state (compare to Fig. 3, $\mathrm{E}$ and F). (G) Microtektite with surface microcrater from the Medford, NJ Exposures. Inset shows several other forms found at Medford, which allows us to exclude drilling contamination as a source of the spherules. See table S4 for abundances. (H) Typical microkrystite from Wilson Lake B (366.2 du). 

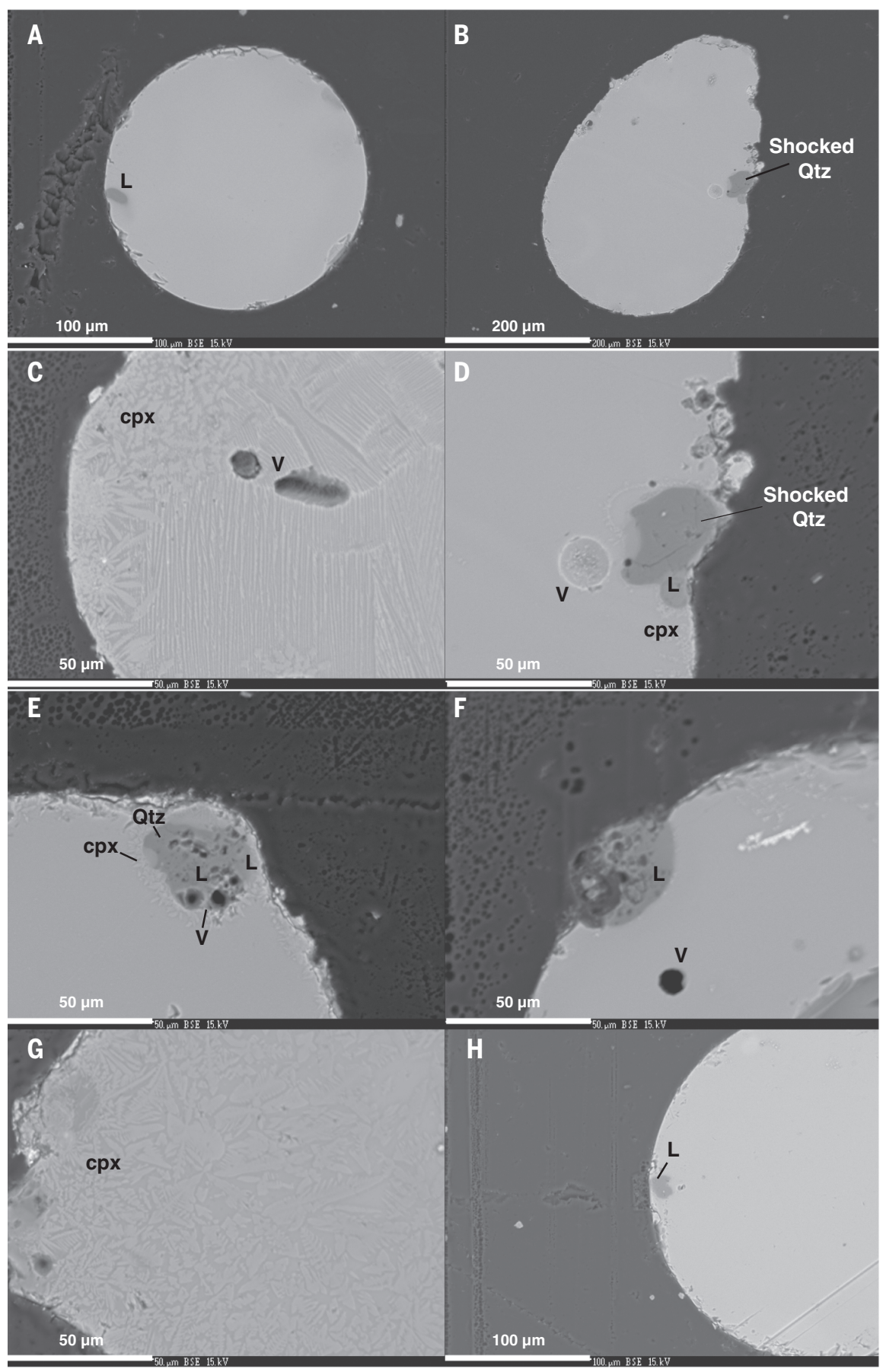

Fig. 3. Electron backscatter (15 kV) images of microtektites and microkrystites from polished cross sections. Scale in micrometers noted by white bars ( $L$, lechatelierite inclusions; $c p x$, clinopyroxene microlites; V, vesicle). (A) Typical internal structure of a glassy microtektite from Wilson Lake B (365.5 du). (B) Teardrop microkrystite from Millville (898.5 du). Note quartz and lechatelierite inclusion at edge. (C) Quench-form crystallite morphologies in a microkrystite from Millville (898.5 du). Note "chain form" and dendritic structures of cpx crystals, typical of rapid quenching from high temperatures. (D) Enlargement of grain inclusion in (B) showing lechatelierite around a quartz grain. Raman spectra from this quartz grain show characteristic vibrational shifts associated with shocked quartz (see fig. S21). Also note fine-grained dendritic cpx microlites at edges of droplet. (E) Vesicular lechatelierite accretion/inclusion surrounded by clinopyroxene microlites from Millville (898.8 du). Light-colored inclusions are iron-rich crystallites (see fig. S16 for details). (F) Microtektite showing accretion of a grain or an exposed inclusion with lechatelierite around it, from Millville (898.8 du). (G) Close-up of microkrystite showing dendritic and feather-form crystallites of clinopyroxene from Hole 1051B (512.75 mbsf). (H) Typical microtektite with small lechatelierite inclusion from Hole 1051B (512.75 mbsf). increases with increasing silica content. These K-Pg spherules are also several times more enriched in $\mathrm{Na}_{2} \mathrm{O}$ (average $\sim 3 \%$ ) compared with the P-E spherules $(0.2 \%)$ and have about half as much $\mathrm{FeO}(5.5 \%$ in the K-Pg versus $10 \%$ in the P-E). The presence of conchoidal fracture patterns in the P-E spherule glass is also inconsistent with surficial exposure and chemical weathering (e.g., Fig. 2 and fig. S2, E and F). The K-Pg ejecta are not preserved as glassy spherules on the coastal plain and are usually diagenetically altered; furthermore, they were buried by 20 to $30 \mathrm{~m}$ of sediment by the time of the P-E boundary (36) and would have been unlikely to survive unaltered on the terrestrial surface for 10 million years before a redeposition event at the P-E boundary. Indeed, the occurrence of the P-E microtektites in a discrete time-correlative stratigraphic layer at three separate locations separated by $>1000 \mathrm{~km}$, two from the New Jersey shelf and one in the open ocean (Blake Nose) (Fig. 1), makes a required focused reworking of relatively rare $\mathrm{K} / \mathrm{Pg}$ spherules highly improbable. In addition, if the spherules were reworked, they would be accompanied by other material of the same age, such as K-Pg microfossils, which would have been much more abundant than spherules. Also, the discovery of spherules at the Medford outcrop section (Fig. 2) (12) that are identical in morphology and chemistry to those at Millville, Wilson Lake B, and Hole $1051 \mathrm{~B}$ confirms that they are not an artifact of drilling disturbance.

We conclude that the spherule layer at Wilson Lake B, Millville, and ODP Site 1051 is best explained as air-fall ejecta (microtektites and microkrystites) generated by an impact close to the time of the P-E boundary. Ejecta fallout occurs over hours or days, implying that the spherule layer provides the most precise time-correlative feature for the P-E boundary among the three sites. The unprecedented high stratigraphic resolution of the Wilson Lake B and Millville sites, where the onset of the CIE is recorded over meters of section, compared with only a few centimeters in open ocean sections [e.g., ODP Sites 1051 and 690 (37)], provides the potential for temporal resolution that has not been heretofore possible and will surely be the target of important future work. Importantly, the virtually instantaneous time line provided by the microtektite horizon provides an opportunity to delineate the detailed sequencing of sedimentation and carbon cycling at a critical juncture in Earth's climate history. For example, the apparent variable offsets between the microtektite horizon and inflections in the bulk sediment $\delta^{13} \mathrm{C}$ curves at Wilson Lake B and Millville, compared to the step function in foraminiferal $\delta^{13} \mathrm{C}$ (fig. S22), must be viewed in this unfamiliar level of ultrahigh resolution and inspire greater scrutiny of the source(s) of the bulk carbon isotope excursion and its relation to the actual sequence of events at the P-E boundary.

It is worth noting that an Ir anomaly has been identified at a P-E boundary section at Zumaya, Spain (38), although it has been interpreted as volcanic in origin (39), and in flysch deposits from Slovenia (40); however, a large iridium anomaly is 


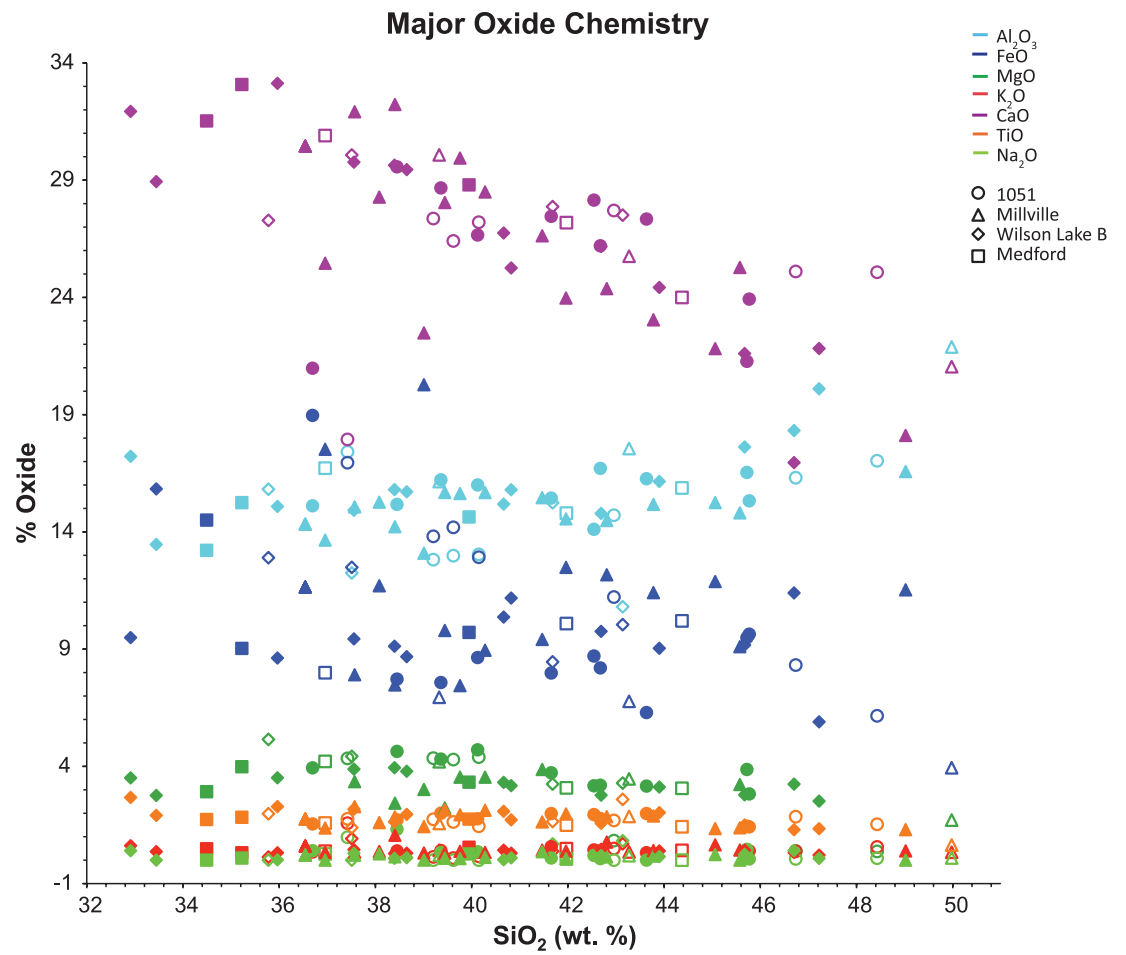

Fig. 4. Microtektite and microkrystite major oxide chemistry from Wilson Lake B, Millville, Medford, and Hole 1051B. Elemental abundances are corrected from EDS spectra and normalized to oxygen, assuming stoichiometry (see table S5). Closed symbols represent microtektites, and open symbols denote microkrystites.

not necessarily associated with all major impacts [e.g., the Chesapeake impact (41)]. These findings will motivate a search for impact ejecta at other sites to define the geographic footprint of the P-E strewn field, which will ultimately constrain the currently unknown location of an impact crater.

\section{REFERENCES AND NOTES}

1. B. P. Glass, Geol. Soc. Am. Bull. 85, 1305-1314 (1974).

2. B. Glass, Tectonophysics $171,393-404$ (1990).

3. B. Glass, C. A. Burns, in Lunar and Planetary Science Conference Proceedings (1988), vol. 18, pp. 455-458.

4. D. Stöffler, J. Non-Cryst. Solids 67, 465-502 (1984).

5. D. Stöffler, F. Langenhorst, Meteoritics 29, 155-181 (1994).

6. B. P. Glass, B. M. Simonson, Distal Impact Ejecta Layers: A Record of Large Impacts in Sedimentary Deposits (Springer Science \& Business Media, 2012).

7. M.-P. Aubry, K. Ouda, C. Dupuis, W. A. Berggren, J. A. van Couvering, Episodes 30, 271-286 (2007).

8. P. J. Sugarman et al., in Proceedings of the Ocean Drilling Program, Initial Reports, K. G. Miller, P. J. Sugarman, J. V. Browning, Eds. (Ocean Drilling Program, College Station, TX, 2005).

9. R. Norris, D. Kroon, A. Klaus, in Proceedings of the Ocean Drilling Program, Initial Reports. (1998), vol. 171, pp. 1-749.

10. J. D. Wright, M. F. Schaller, Proc. Natl. Acad. Sci. U.S.A. 110, 15908-15913 (2013)

11. M. E. Katz, D. K. Pak, G. R. Dickens, K. G. Miller, Science 286 1531-1533 (1999)

12. All primary data are available as supplementary materials on Science Online.

13. S. Liu, B. Glass, F. T. Kyte, S. M. Bohaty, The late Eocene clinopyroxene-bearing spherule layer: New sites, nature of the strewn field, Ir data, and discovery of coesite and shocked quartz. Geolog. Soc. Am. Spec. Pap. 452, 37-70 (2009).

14. C. W. Poag, Sediment. Geol. 108, $45-90$ (1997).

15. F. Langenhorst, Geology 24, 487-490 (1996).

16. B. P. Glass, S. Liu, A. Montanari, Meteorit. Planet. Sci. 39 , 589-597 (2004).

17. B. P. Glass, Chemie Erde Geochem. 62, 173-196 (2002).

18. B. P. Glass, H. Huber, C. Koeberl, Geochim. Cosmochim. Acta 68, 3971-4006 (2004).

19. C. Koeberl, Tectonophysics $171,405-422$ (1990).

20. C. Koeberl, Geolog. Soc. Am. Spec. Pap. 293, 133-152 (1992).
21. C. Koeberl, A. Beran, in Lunar and Planetary Science Conference Proceedings (1988), vol. 18, pp. 403-408.

22. A. Beran, C. Koeberl, Meteorit. Planet. Sci. 32, 211-216 (1997).

23. H. Melosh, N. Artemieva, Lunar Planet. Sci. XXXV, 1723 (2004).

\section{PROTEIN EVOLUTION} Francesc Posas, ${ }^{3}$ Pedro Beltrao, ${ }^{1,4} \dagger$ Judit Villén ${ }^{2} \dagger$ ivergence in transcriptional regulation and gene expression is often considered the main driver of phenotypic variation across species (1). Comparative gene expression and chromatin immunoprecipitation se-
24. D. Parkin, R. Sullivan, J. Andrews, Philos. Trans. R. Soc. London A: Math. Phys. Eng. Sci. 297, 495-518 (1980).

25. D. Stöffler et al.. Rev. Mineral. Geochem. 60, 519-596 (2006). 26. A. J. Gratz, D. K. Fisler, B. F. Bohor, Earth Planet. Sci. Lett. 142 513-521 (1996)

27. P. F. McMillan, G. H. Wolf, P. Lambert, Phys. Chem. Miner. 19 , 71-79 (1992).

28. H. Vonhof, J. Smit, Meteorit Planet Sci. 34, 747-755 (1999).

29. C. John, B. P. Glass, Geology 2, 599-602 (1974).

30. B. Glass, C. A. Burns, J. R. Crosbie, D. L. DuBois, J. Geophys. Res. Solid Earth 90 (S01), 175-196 (1985).

31. S. Liu, D. Papanastassiou, H. Ngo, B. Glass, Meteorit. Planet. Sci. 41, 705-714 (2006).

32. H. D. Bermúdez et al., Terra Nova 28, 83-90 (2016).

33. S. L. D'Hondt, G. Keller, R. F. Stallard, Meteoritics 22, 61-79 (1987)

34. R. K. Olsson, K. G. Miller, J. V. Browning, D. Habib,

P. J. Sugarman, Geology 25, 759-762 (1997)

35. W. Alvarez et al., Geology 20, 697-700 (1992)

36. A. D. Harris et al., Paleoceanography 25, PA3211 (2010)

37. S. Bains, R. M. Corfield, R. D. Norris, Science 285, 724-727 (1999)

38. B. Schmitz et al., Palaeogeogr. Palaeoclimatol. Palaeoecol. 133 49-68 (1997).

39. B. Schmitz et al., Earth Planet. Sci. Lett. 225, 1-17 (2004).

40. T. Dolenec, J. Pavšič, S. Lojen, Terra Nova 12, 199-204 (2000)

41. A. Montanari, F. Asaro, H. V. Michel, J. P. Kennett, Palaios 8 , 420-437 (1993)

\section{ACKNOWLEDGMENTS}

We thank L. Lanci, B. Glass, and E. B. Watson for many helpful discussions. Samples were provided by IODP, which is sponsored by NSF and participating countries under management of the Joint Oceanographic Institutions, Inc. We also thank J. Singer for his help and expertise on the ion microprobe at RPI and C. Hoff for his valuable expertise in FTIR and Raman spectroscopy. We thank the four anonymous reviewers for their constructive input, which greatly strengthened this manuscript. This work was funded in part by the Comer Science and Education Foundation. LDEO contribution 8060.

\section{SUPPLEMENTARY MATERIALS}

www.sciencemag.org/content/354/6309/225/suppl/DC1 Supplementary Text

Figs. S1 to S22

Tables S1 to S6

References (42-49)

25 February 2016; accepted 16 September 2016

10.1126/science.aaf5466

\section{Evolution of protein phosphorylation across 18 fungal species}

Romain A. Studer, ${ }^{1 *}$ Ricard A. Rodriguez-Mias, ${ }^{2 *}$ Kelsey M. Haas, ${ }^{2 *}$ Joanne I. Hsu, ${ }^{2}$ Cristina Viéitez, ${ }^{3,4}$ Carme Solé, ${ }^{3}$ Danielle L. Swaney, ${ }^{2}$ Lindsay B. Stanford, ${ }^{2}$ Ivan Liachko, ${ }^{2}$ René Böttcher, ${ }^{3}$ Maitreya J. Dunham, ${ }^{2}$ Eulàlia de Nadal, ${ }^{3}$

Living organisms have evolved protein phosphorylation, a rapid and versatile mechanism that drives signaling and regulates protein function. We report the phosphoproteomes of 18 fungal species and a phylogenetic-based approach to study phosphosite evolution. We observe rapid divergence, with only a small fraction of phosphosites conserved over hundreds of millions of years. Relative to recently acquired phosphosites, ancient sites are enriched at protein interfaces and are more likely to be functionally important, as we show for sites on H2A1 and elF4E. We also observe a change in phosphorylation motif frequencies and kinase activities that coincides with the wholegenome duplication event. Our results provide an evolutionary history for phosphosites and suggest that rapid evolution of phosphorylation can contribute strongly to phenotypic diversity.

quencing studies show that transcriptional regulation has diverged very quickly (2). Similar analysis of protein posttranslational regulation has lagged due to methodological limitations. Now, mass spectrometry (MS) allows comprehensive 


\section{Supplementary Materials for}

\section{Impact ejecta at the Paleocene-Eocene boundary \\ Morgan F. Schaller,* Megan K. Fung, James D. Wright, Miriam E. Katz, Dennis V. Kent}

*Corresponding author. Email: schall@rpi.edu

Published 14 October 2016, Science 354, 225 (2016)

DOI: $10.1126 /$ science.aaf5466

This PDF file includes:

Materials and Methods

Supplementary Text

Figs. S1 to S22

Tables S1 to S6

References 


\section{Materials and Methods}

Samples of $\sim 30-40 \mathrm{~g}$ dry weight (where available) were taken below and through the onset of the CIE from the Wilson Lake B and Millville cores, avoiding any portions showing evidence of drilling mud injection. At ODP Hole 1051B, we used samples taken for foraminiferal assemblages and isotopes (11), with sample sizes between 2 and $20 \mathrm{~g}$. Sediment samples were soaked in DI, washed through a $63 \mu \mathrm{m}$ sieve and dried in an oven at $50^{\circ} \mathrm{C}$. Spherules were picked manually from the $>63 \mu \mathrm{m}$ size fraction and reported as number of spherules per gram of dry (unwashed) sediment. The shelf sediments from the Marlboro clay are dominated by kayolinite and illite clays with silts in the fine fraction, and glauconite, quartz and mica in the $>63 \mu \mathrm{m}$ size fraction (42). At site 1051 the fine fraction is mostly coccoliths, with radiolaria and foramnifera and occasional clasitic grains (quartz) in the course fraction. To minimize potential observational bias, samples were randomized by a disinterested third party, and those picking were not aware of which samples were likely to encompass the spherule layer and searches of each sample (including those where no glassy spherules were recovered) were allotted up to 50 hours . Spherules were mounted on glass slides for micro-laser Raman spectroscopy using the Bruker $532 \mathrm{~nm}$ green laser system at RPI. Separate grain mounts of glass particles were carbon-coated for analysis by SEM or ion microprobe. Selected samples were mounted in epoxy and polished using a $0.03 \mu \mathrm{m}$ grit to reveal their cross sections, which were also analyzed by Raman spectroscopy. Energy-dispersive X-ray spectroscopy (EDS) measurements were made using a Bruker $\mathrm{x}$-flash 5010 detector (with Be window) mounted on the Cameca SX-100 ion microprobe at RPI for both grain and epoxy mounts. Quantitative major element chemistries were determined by companion EDS measurements of standard glasses and minerals. At least two EDS spectra were generated for each specimen and averaged after removal of background using Bruker's Esprit software. Chemistries were normalized to major oxides assuming stoichiometry.

\section{Supplementary Text}

The Paleocene-Eocene boundary at Wilson Lake and implications for other coastal plain sections

The Paleocene-Eocene boundary is defined by a global decrease in $\delta^{13} \mathrm{C}$ going up section (7) recorded in marine settings by foraminifers, bulk sediments (dominated by nannofossils) and organic matter $(37,43-44)$. Terrestrial sections record large $\delta^{13} \mathrm{C}$ decreases in paleosols, mammalian teeth, and terrestrial and lacustrine organic matter (45, 46). At most sites, the onset occurs over thin stratigraphic intervals with few if any transitional $\delta^{13} \mathrm{C}$ values, allowing unambiguous placement of the P-E boundary.

However, the Atlantic coastal plain from Virginia to New Jersey yields expanded records of the onset with many intermediate values, indicating a dramatic increase in sedimentation rates and an unprecedented chronicle of events across the P-E boundary (10).

At Wilson Lake, the CIE onset differs in placement depending whether the inorganic $\delta^{13} \mathrm{C}$ record from bulk sediments is used versus other $\delta^{13} \mathrm{C}$ recorders, with the bulk decrease starting $\sim 1.2 \mathrm{~m}$ below the organic $\delta^{13} \mathrm{C}$ measurements (47). The scarcity of foraminifers in the coarse-grained, glauconitic, sandy silts (Vincentown Formation in 
New Jersey and Aquia Formation in Maryland/Virginia) below the Marlboro Clay make the bulk records attractive for correlation and boundary placement. Figure S13 shows the relationships between the bulk and foraminiferal $\delta^{13} \mathrm{C}$ at Wilson Lake A (48) along with the Sluijs et al. (47) pick for the onset of the CIE (and hence the P-E boundary) based on dinoflagellate $\delta^{13} \mathrm{C}$ values. We agree with Sluijs et al. (47) on this placement, giving more weight to the foraminiferal and dinoflagellate $\delta^{13} \mathrm{C}$ records over the bulk carbonate record. This also corresponds to the change in lithology from glauconitic sandy silts to the clayey silts of the Marlboro Clay (49) and the major decrease in $\% \mathrm{CaCO}_{3}$ that is common at the onset of the CIE $(10,47)$.

The bulk $\delta^{13} \mathrm{C}$ records show that the nearby (within $\sim 50$ meters) Wilson Lake $-\mathrm{A}$ and $-\mathrm{B}$ core depths can be precisely correlated, but are offset by $\sim 1.5 \mathrm{~m}$ ( $\sim 5$ feet $)$ with common features being deeper in the B-Hole. Mapping the Sluijs et al. pick for the P-E boundary based on dinoflagellate $\delta^{13} \mathrm{C}$ values from the A-Hole to the B-Hole places it at

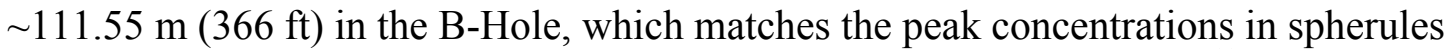
(Figure S22). The process(es) that may have produced the lead in bulk $\delta^{13} \mathrm{C}$ relative to the other $\delta^{13} \mathrm{C}$ records across the onset of the CIE will be the subject of further study. 


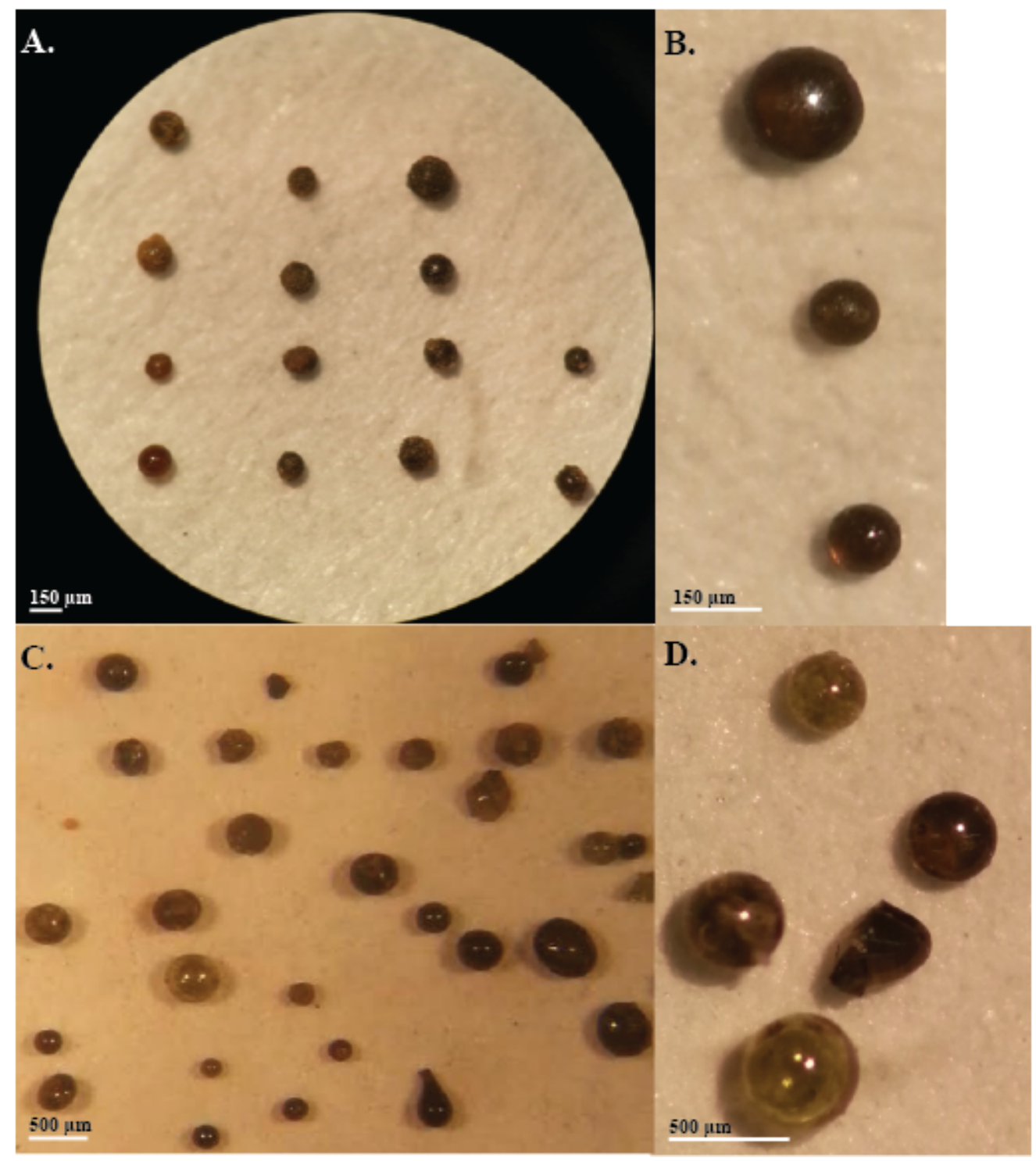

\section{Fig. S1.}

Light Micrographs of spherules from Wilson Lake B and Millville. A. Microtektites and microkrystites from Wilson Lake B $(366.2 \mathrm{du})$, B. Enlargement of various microtektites from Wilson Lake B (366.2 du, drilling units, in decimal feet), C. Microtektites and microkrysites from Millville ( $898.8 \mathrm{du})$, D. Enlargement of spherules and broken rotational form from Millville ( $898.8 \mathrm{du})$. 


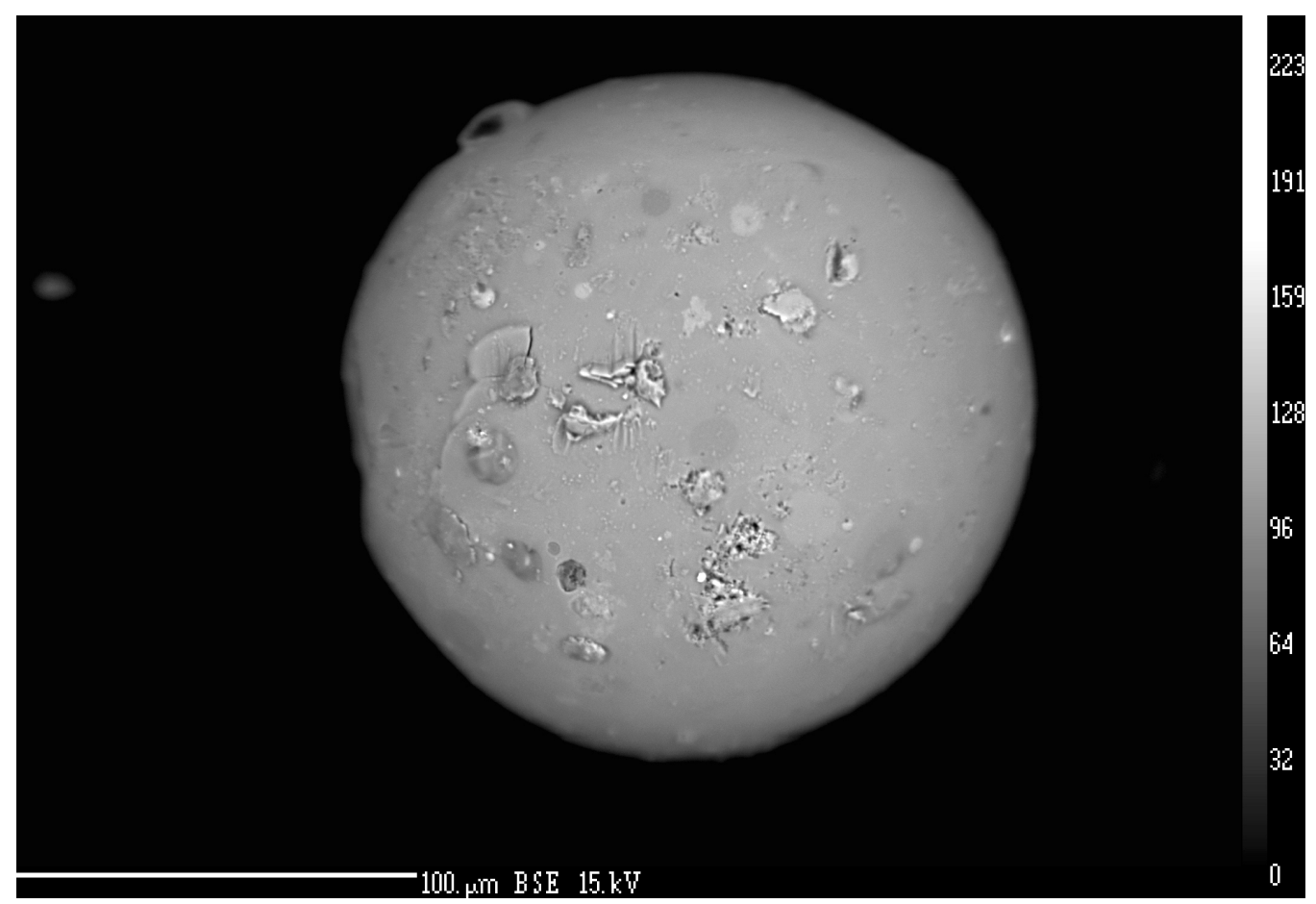

Fig. $\mathbf{S 2}$

Electron backscatter $(15 \mathrm{kV})$ image of a microtektite from Wilson Lake B (365.9 drilling units $(\mathrm{du})$ ). Images are taken using a CAMECA SX100 on the ion microprobe at RPI. Scale in microns noted by white bars, standard contrast scale with saturation is shown to the right of each image. 


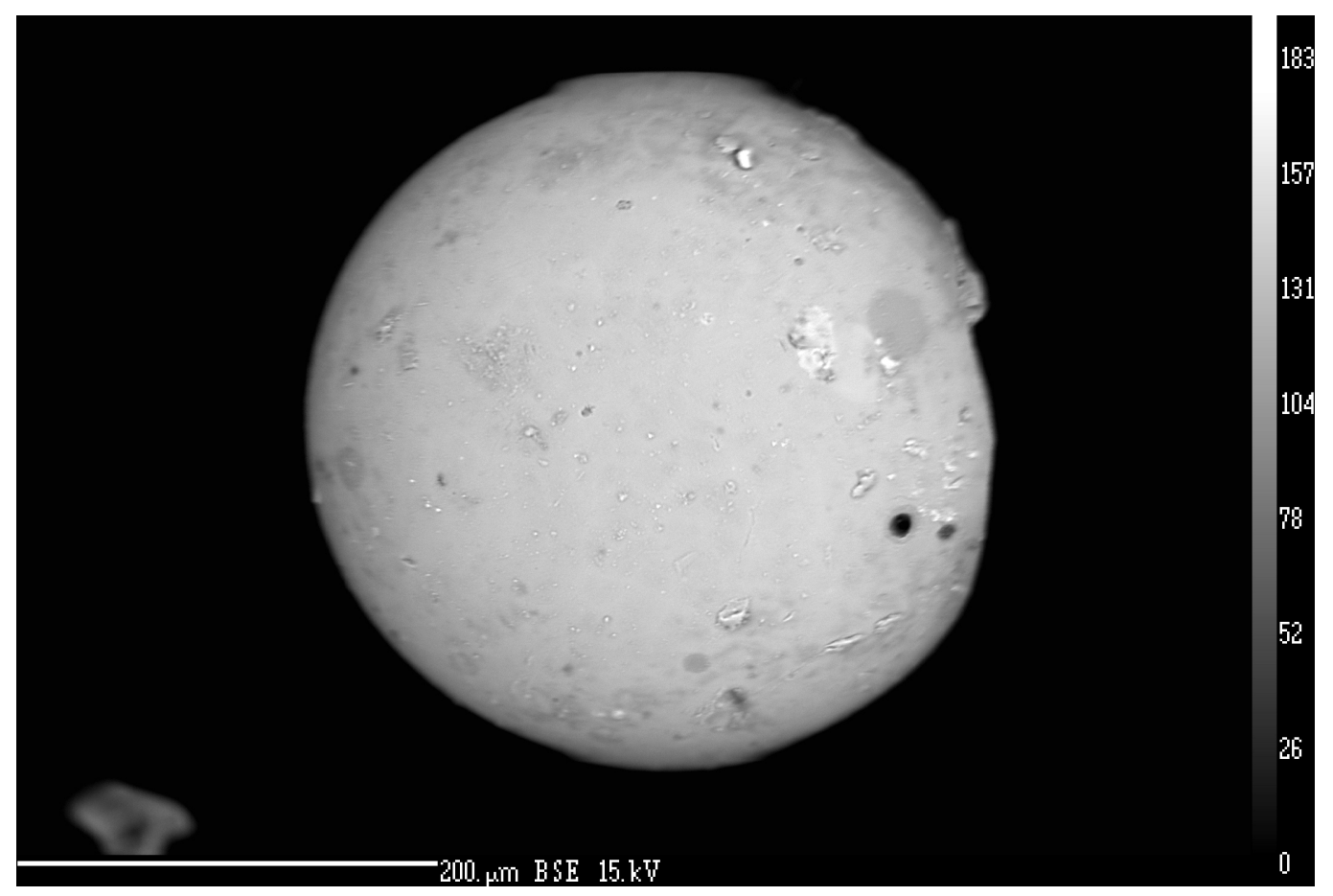

Fig. S3

Microtektite from Wilson Lake B (365.9 du). 


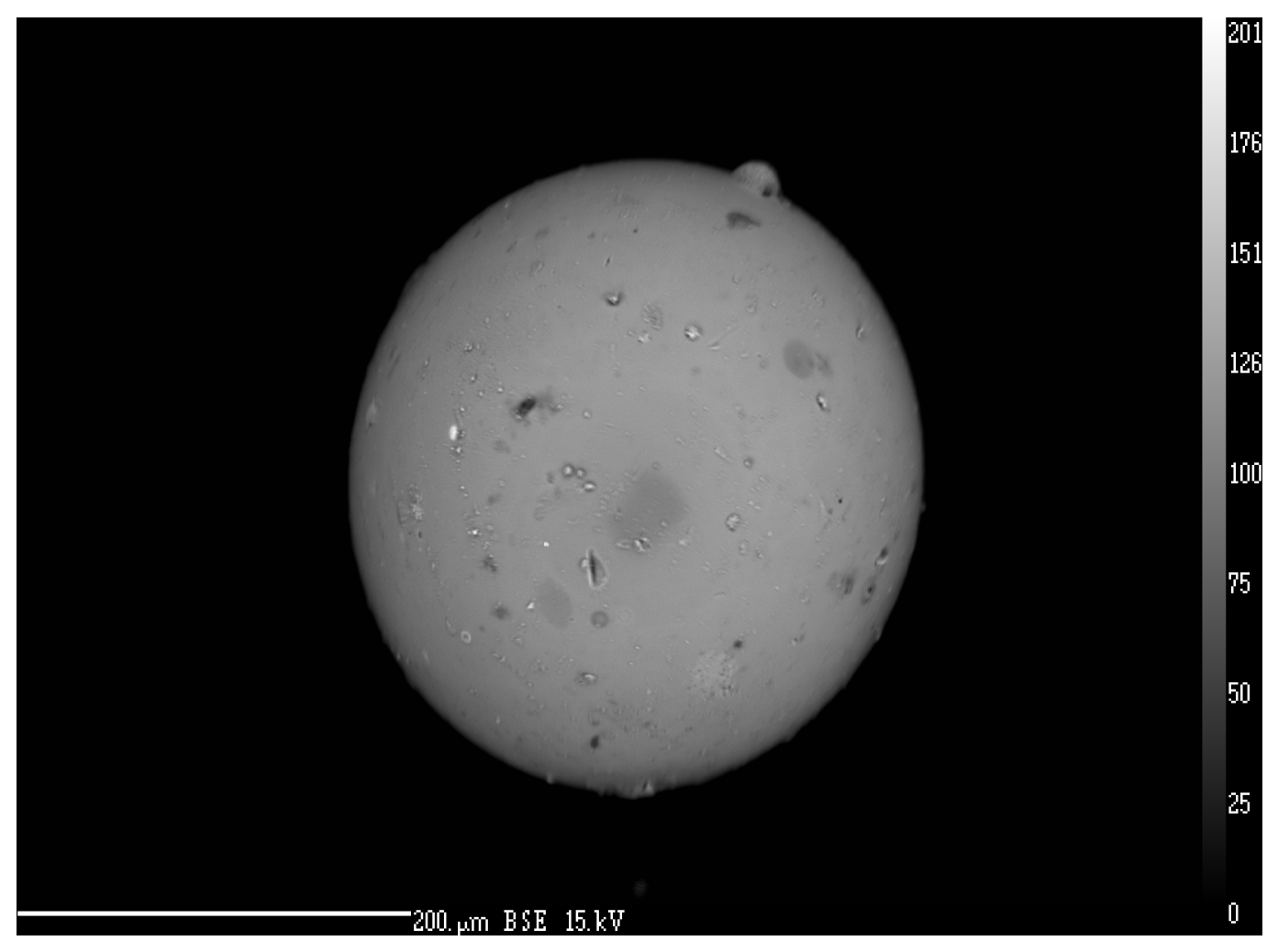

Fig. S4

Microtektite from Hole 1051B (512.75 mbsf). 


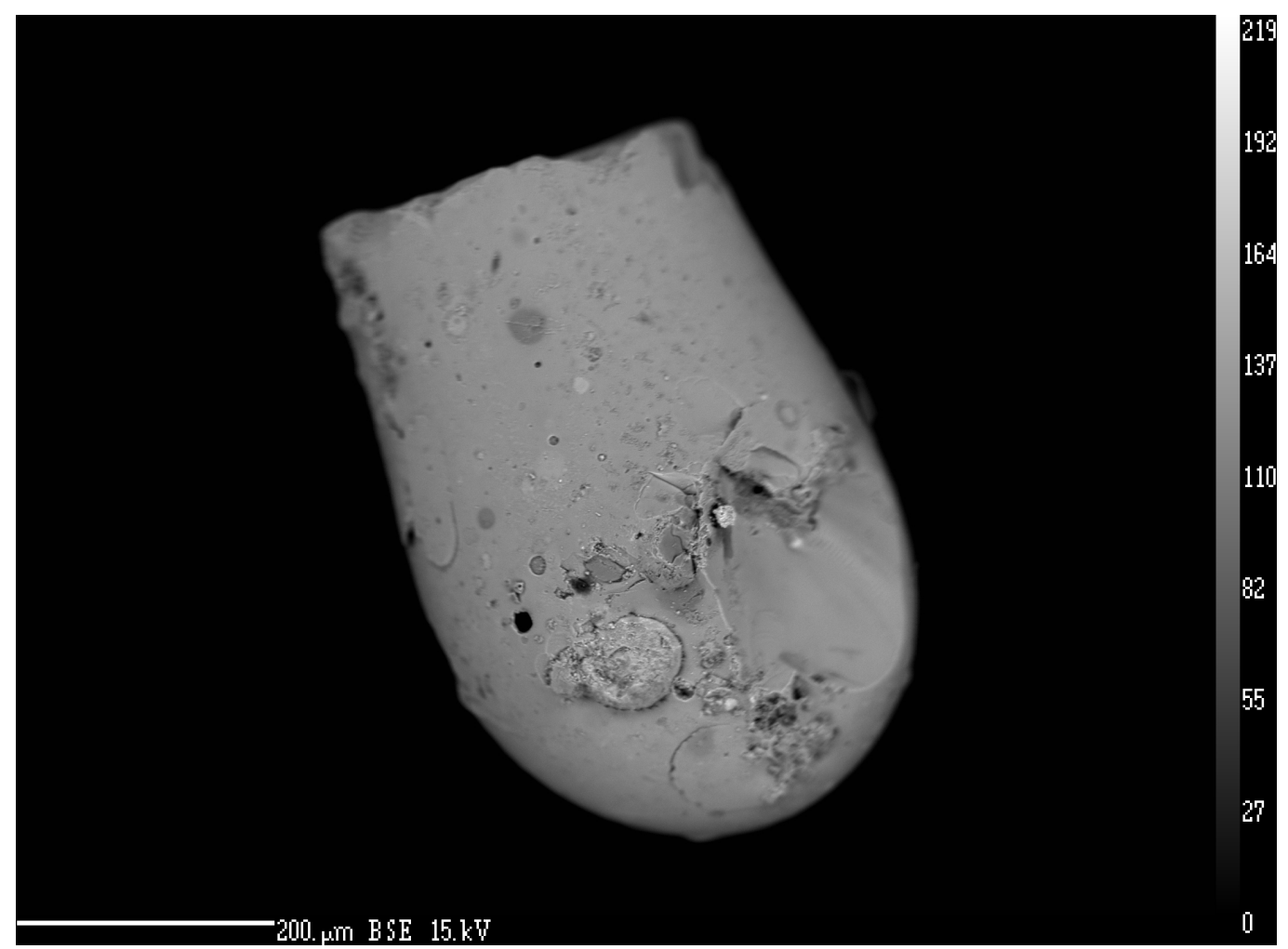

Fig. S5

Rotational form microtektite from Medford outcrop $(3.81 \mathrm{~cm})$. 


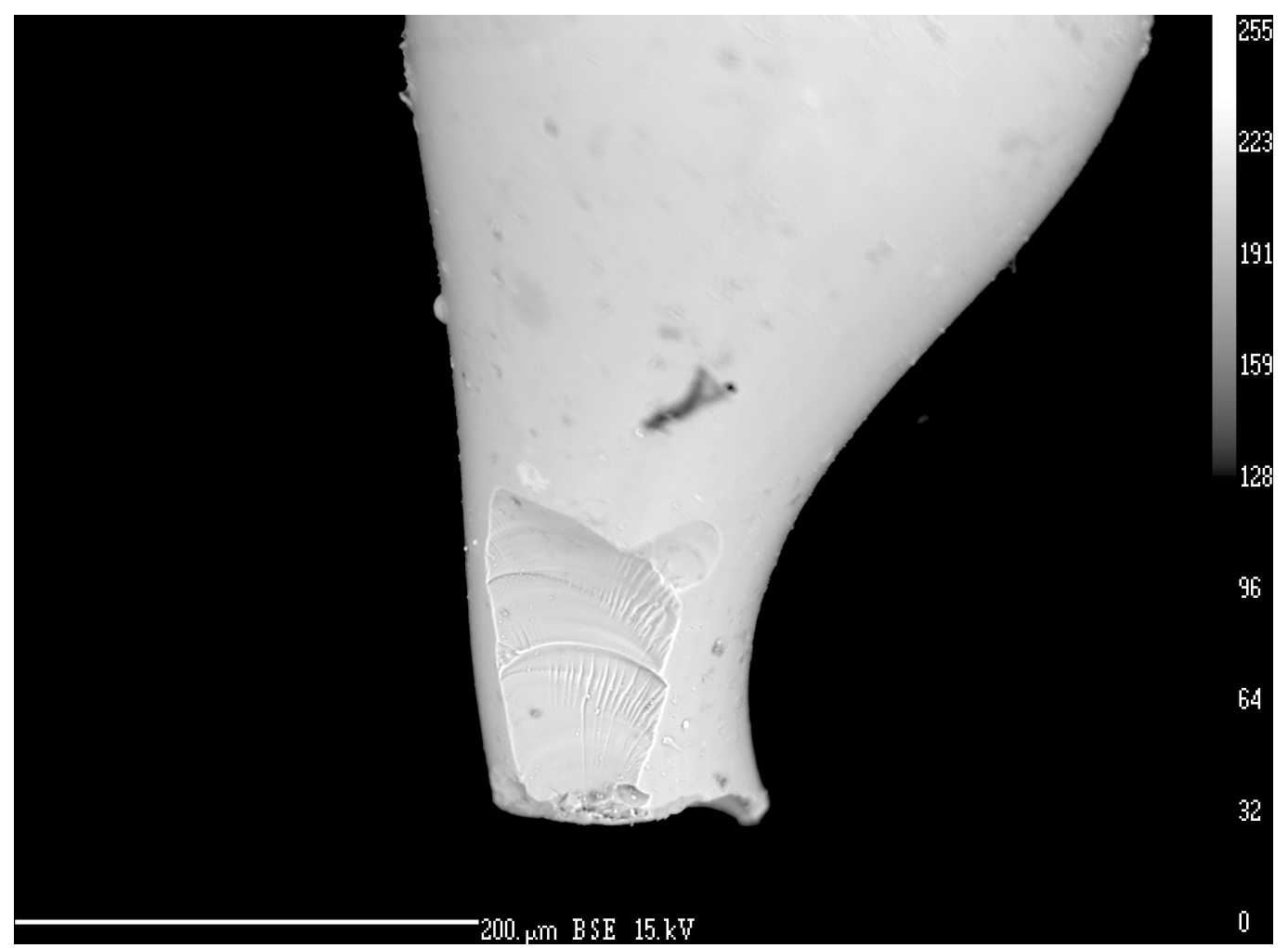

Fig. S6

Rotational form microtektite from Millville (898.8 du). 


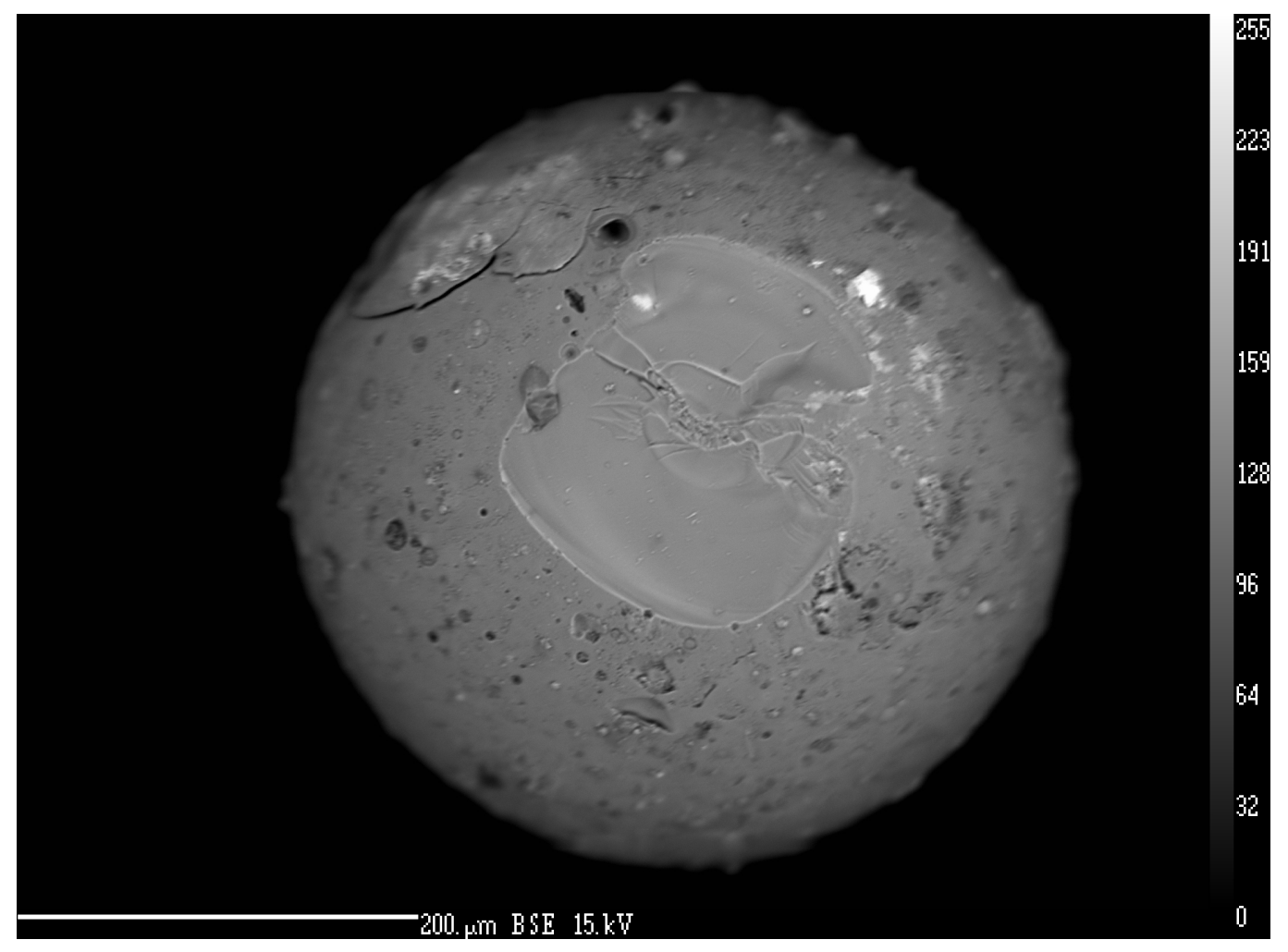

Fig. $\mathbf{S 7}$

Microkrystite from Medford outcrop with a microcrater. 


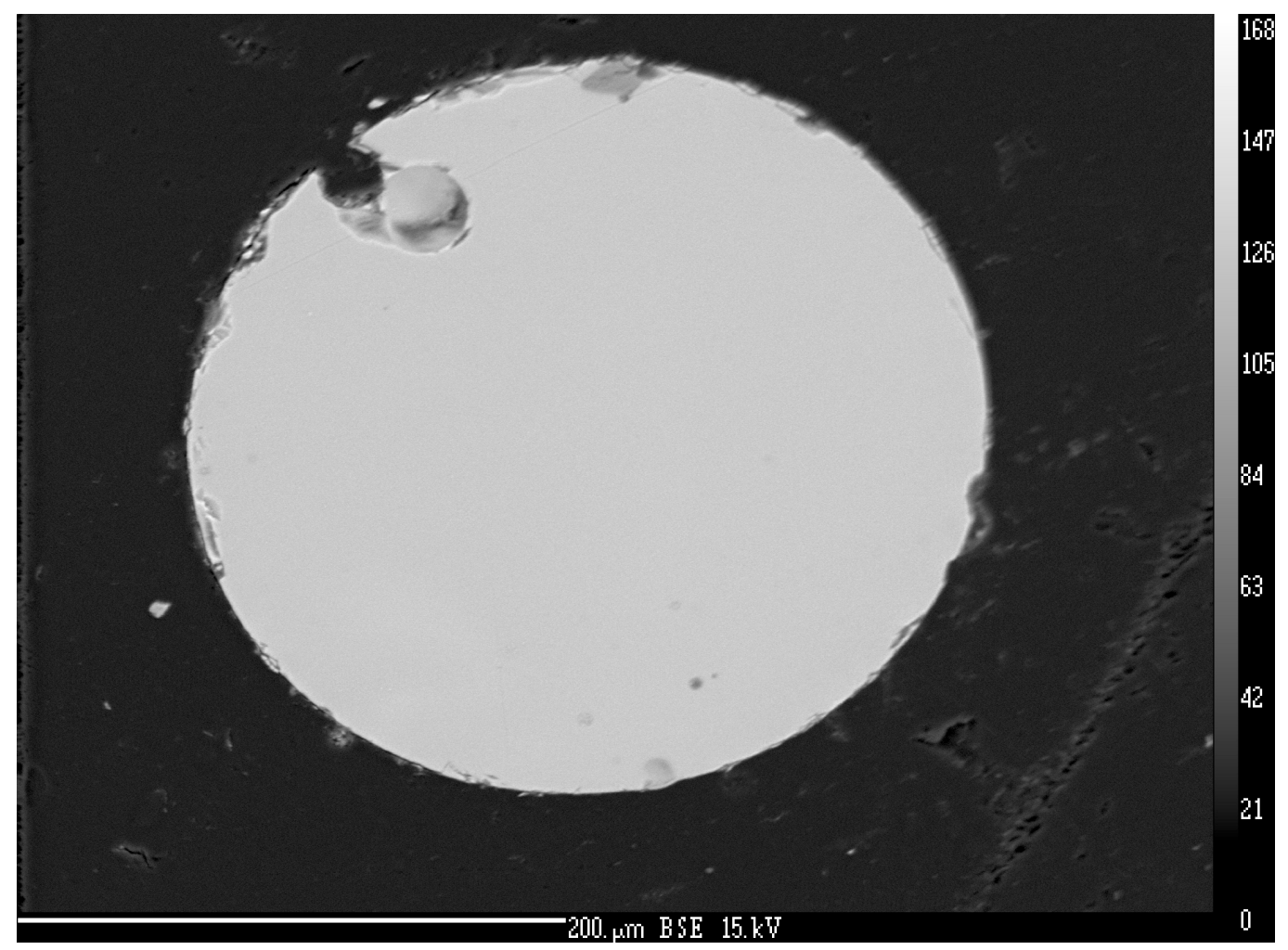

\section{Fig. S8}

Electron backscatter $(15 \mathrm{kV})$ image of a polished cross-section of a microtektite from Millville $(898.8 \mathrm{du})$. Inclusion on top is probably lechatelierite. Images are taken using a CAMECA SX100 on the ion microprobe at RPI. 


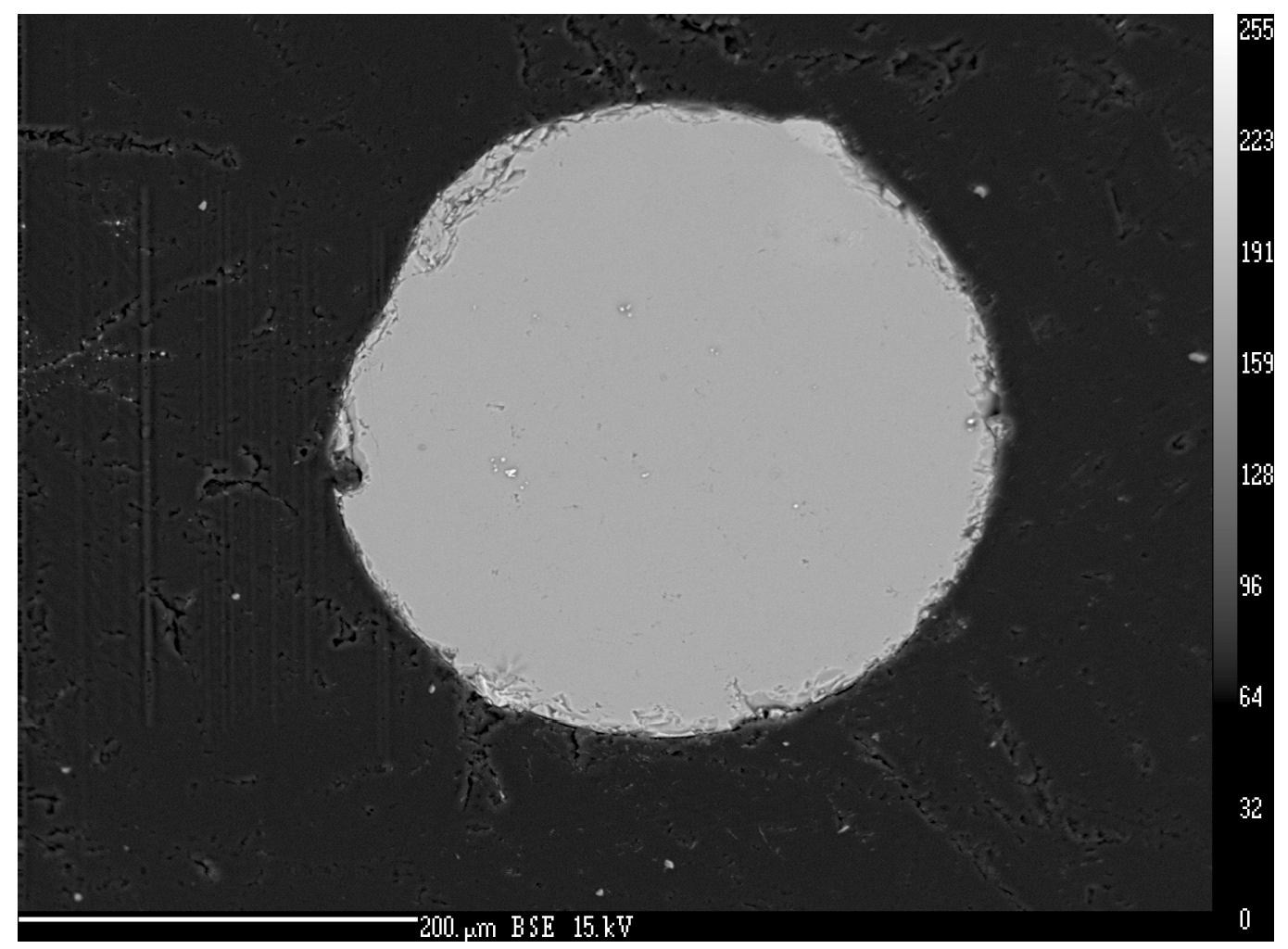

Fig. S9

Microtektite from Wilson Lake B (265.9 du). Bright spots are dust particles. 


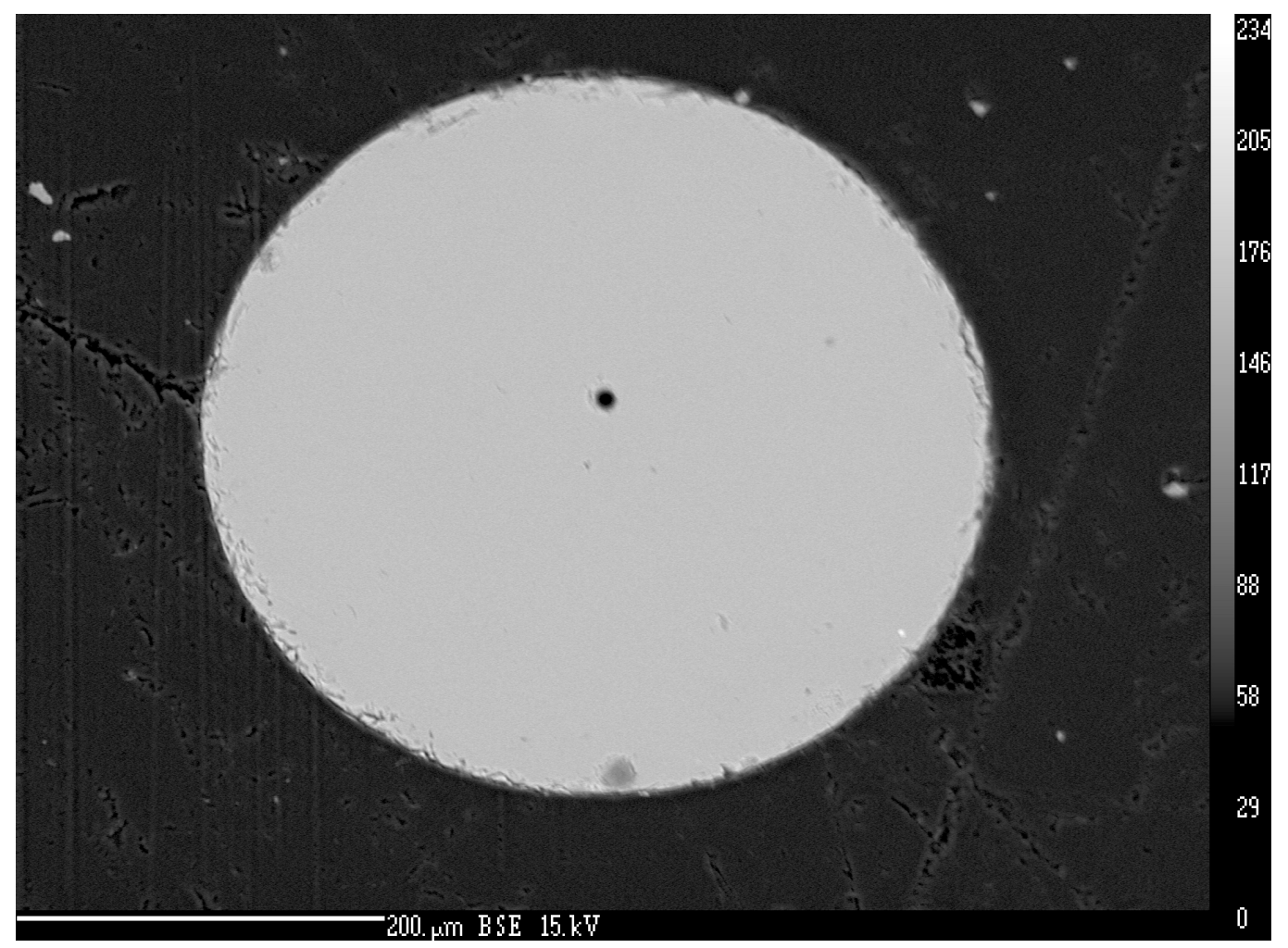

Fig. S10

Microtektite from Hole 1051B (512.75 mbsf). Inclusion at bottom is probably lechatelierite, dark spot at center is a vesicle. 


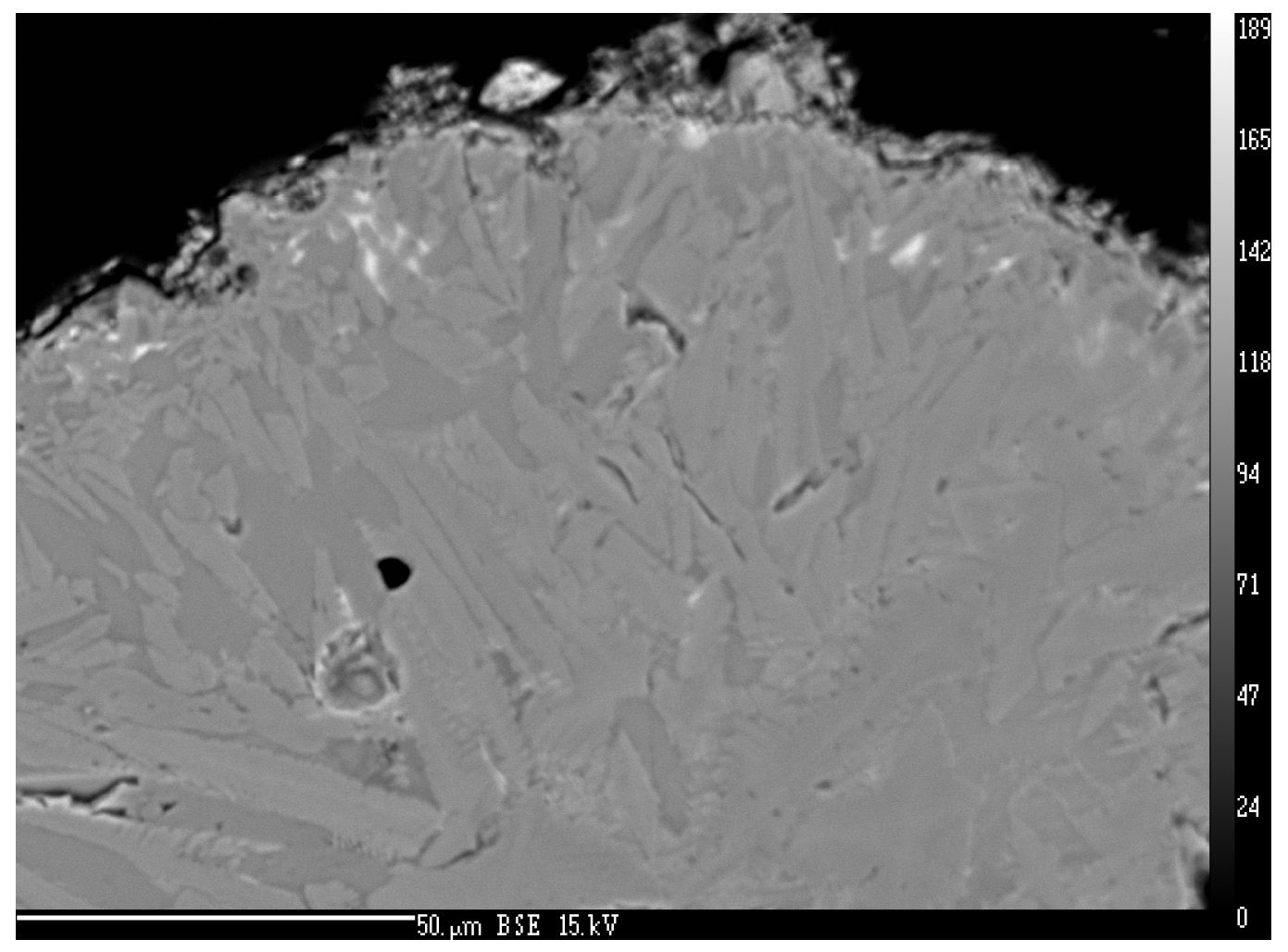

Fig. S11

Close-up of Microkrystite from Wilson Lake B (365.5 du) showing lath-like and featherform crystallites of clinopyroxene (cpx). 


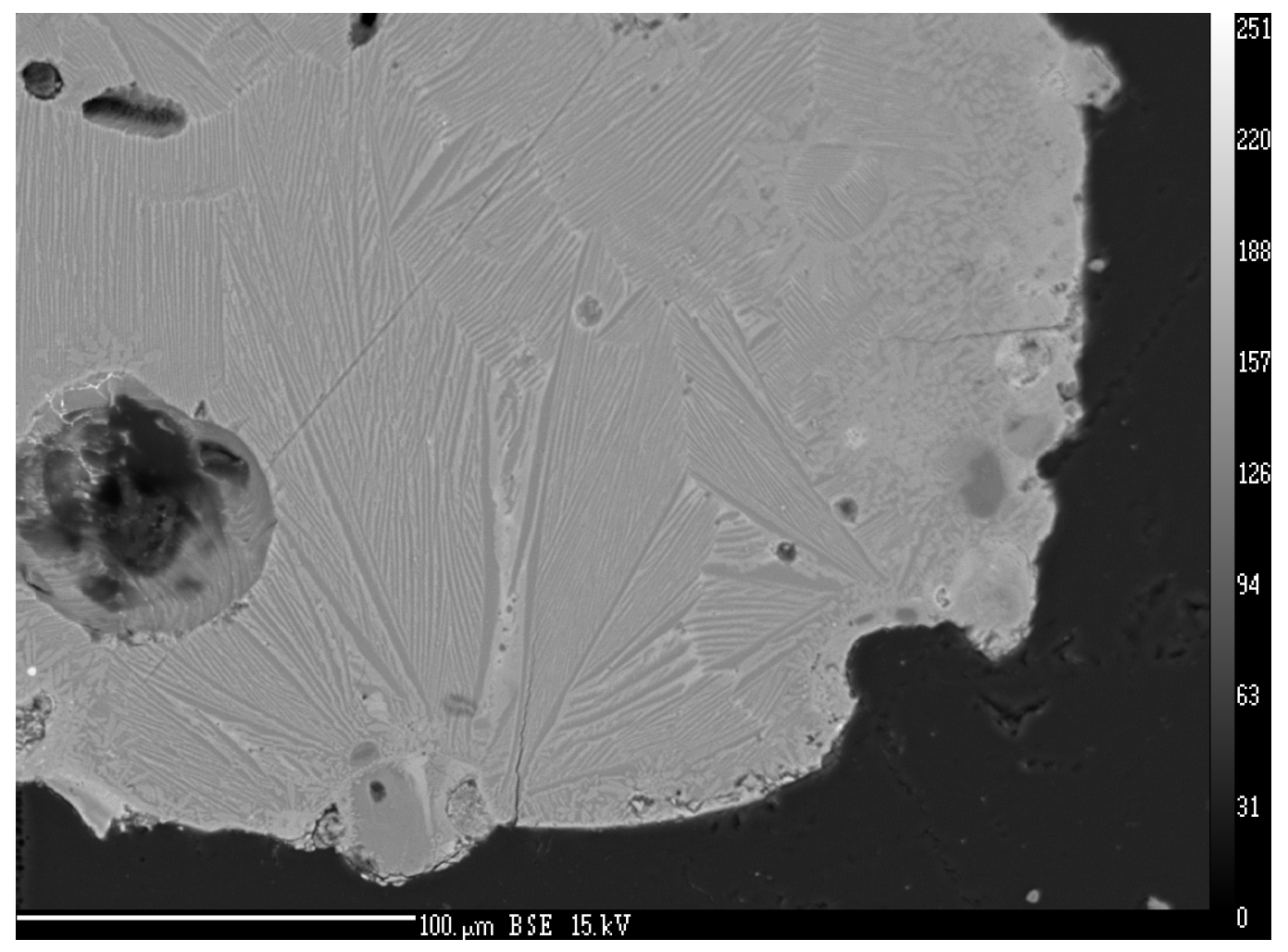

Fig. S12

Blown-up image of a microkrystite from Millville (898.5 du) showing dendritic clinopyroxene crystallites and lechatelierite inclusions (both at right) side. 


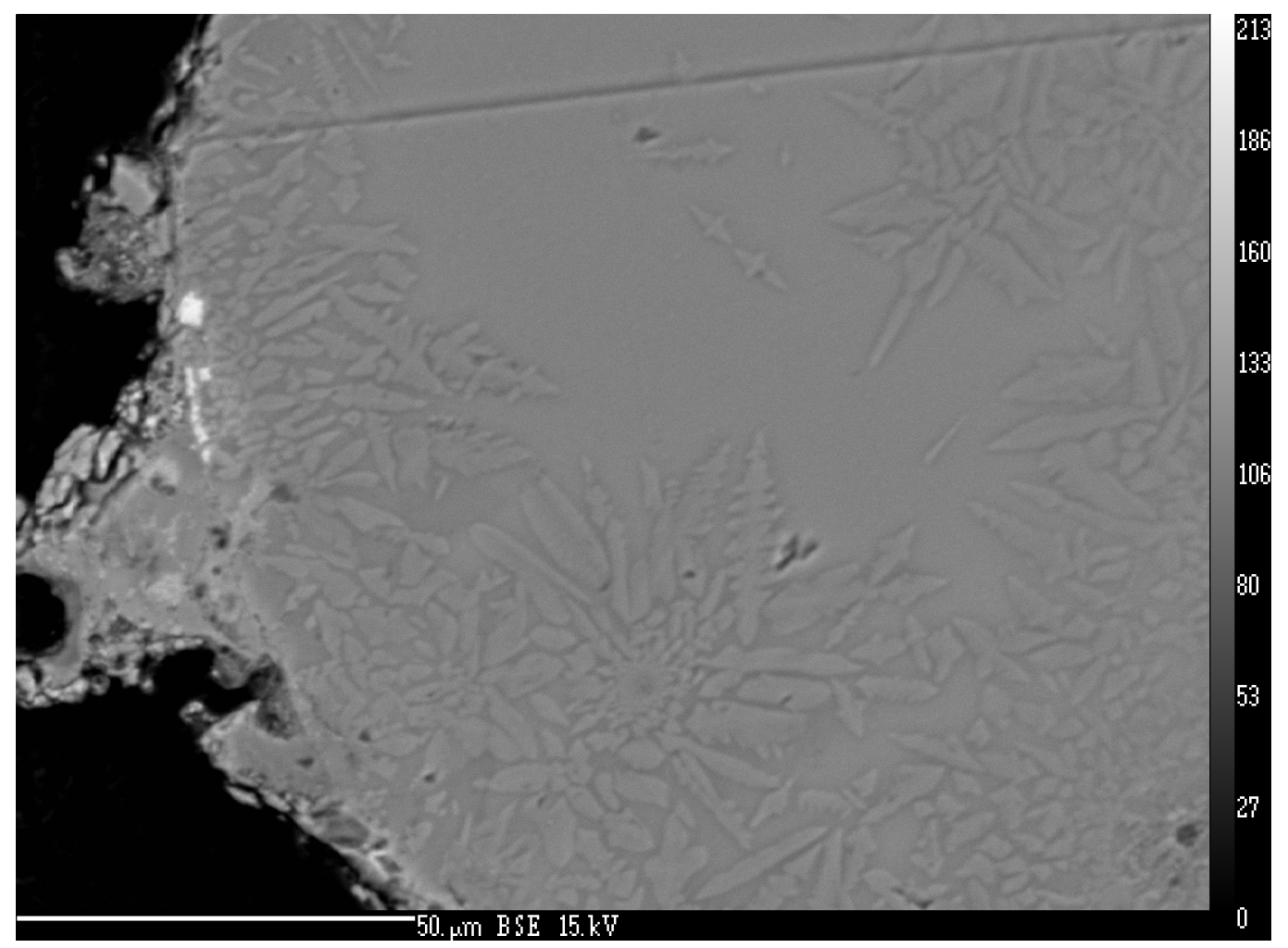

Fig. S13

Microkrystite from Wilson Lake (365.5 du) showing feathered texture of cpx crystals. 


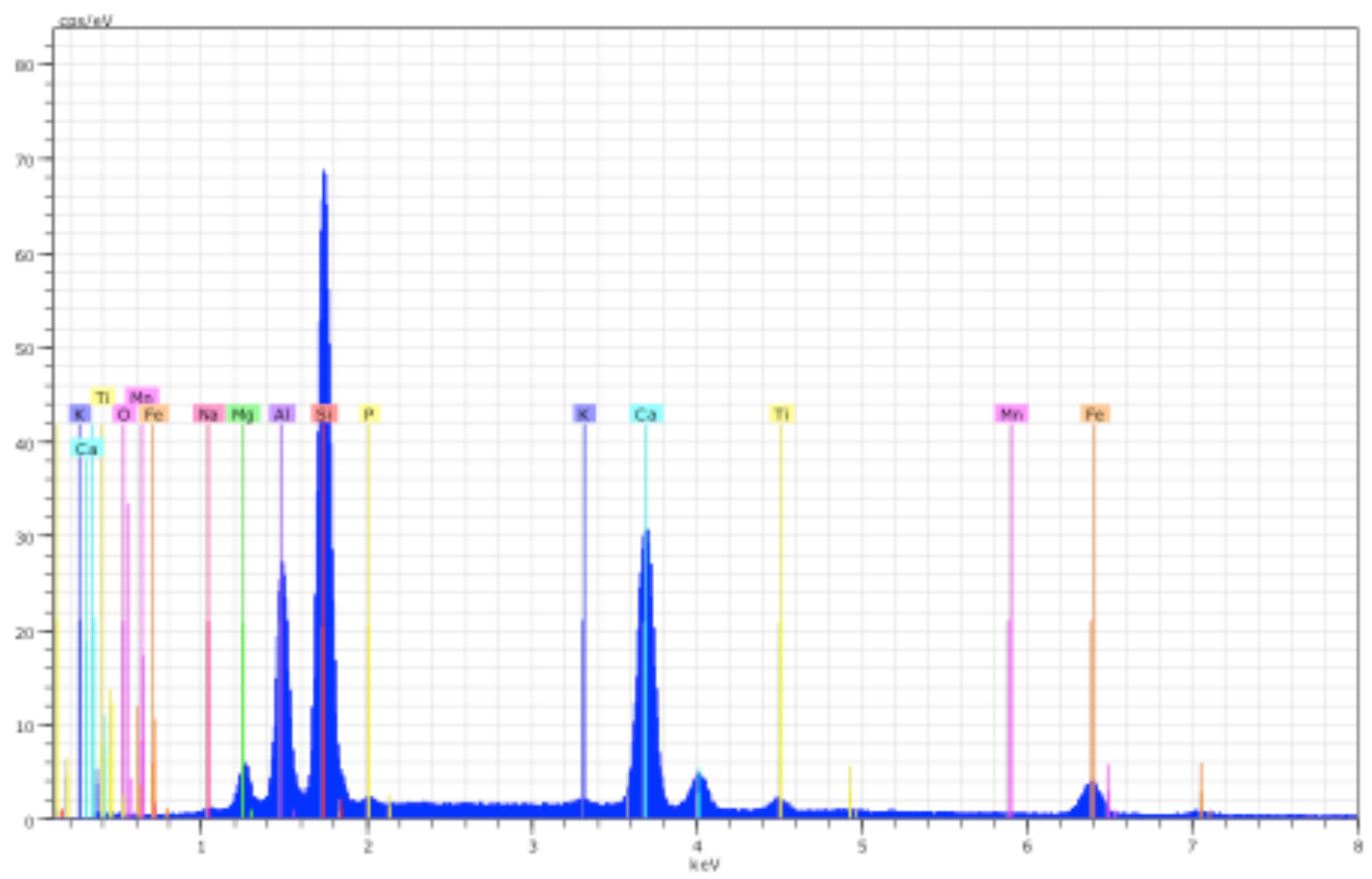

Fig. S14

Energy-dispersive X-ray spectroscopy (EDS) spectrum of a representative polished crosssection of a microtektite matrix from Hole 1051B (512.75 mbsf). EDS measurements are made using the Bruker $\mathrm{x}$ flash 5010 detector (with Be window) and background corrected on the Esprit v.1.8 software. $\mathrm{Y}$-axis in $\mathrm{cps} / \mathrm{eV}$. 


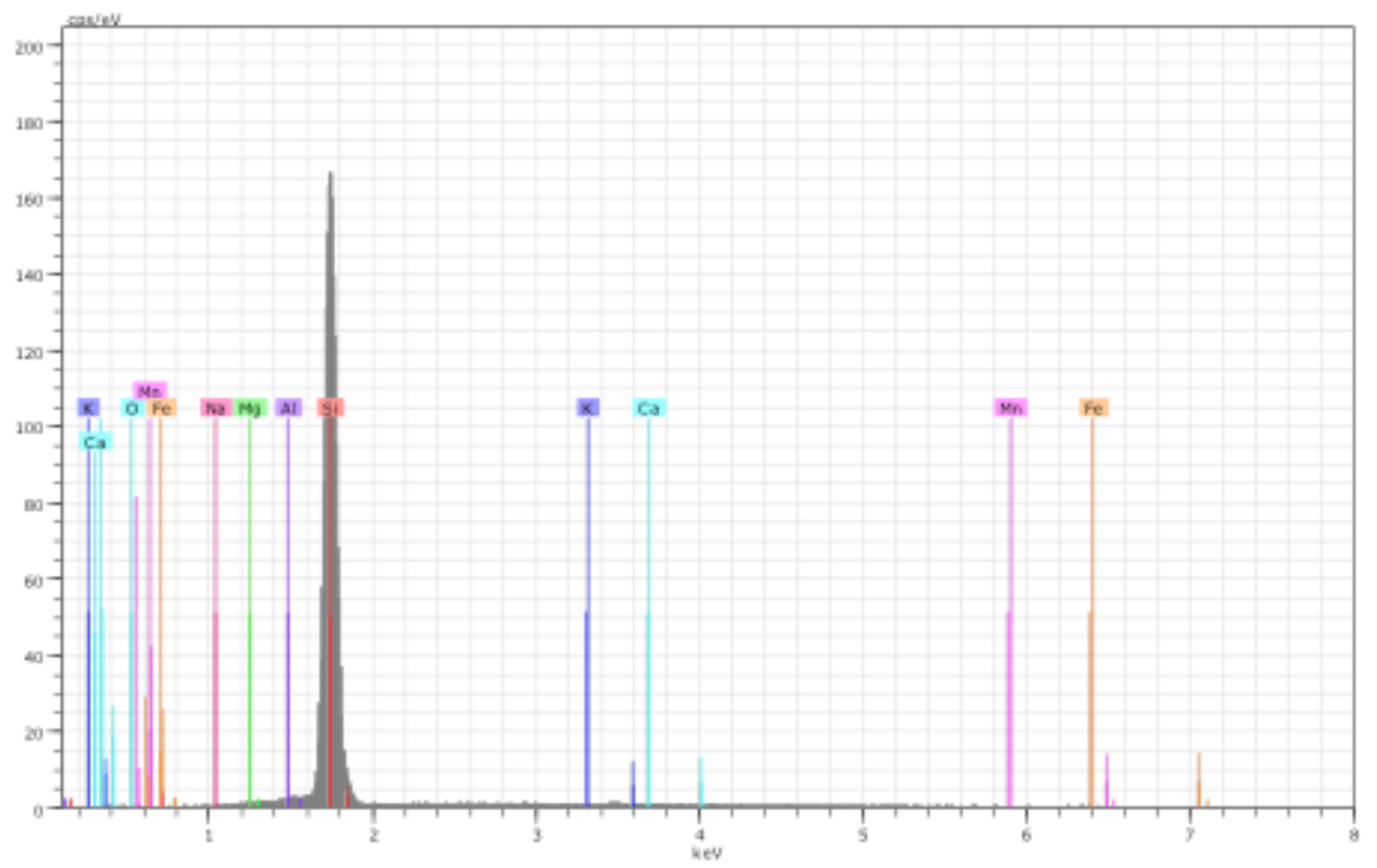

Fig. S15

EDS spectrum of a representative lechatelierite inclusion in a microtektite from Millville (898.5 du). 

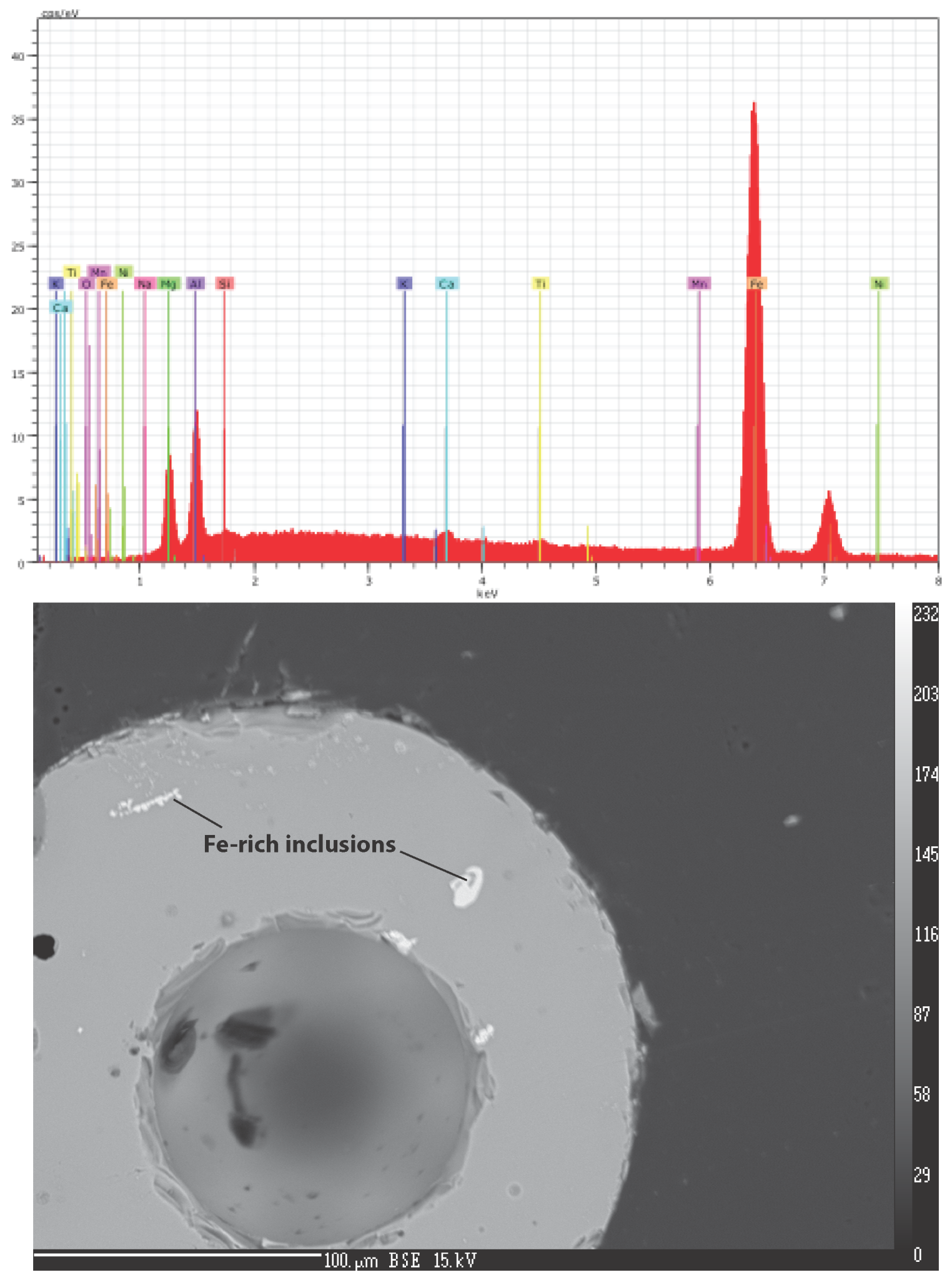


\section{Fig. S16}

Backscatter image (bottom) and EDS spectrum (top) of an iron-rich inclusion in a microtektite from Millville ( $898.8 \mathrm{du})$. The EDS measurement is from the inclusion on the right. Note the large vesicle near the center of the spherule. 


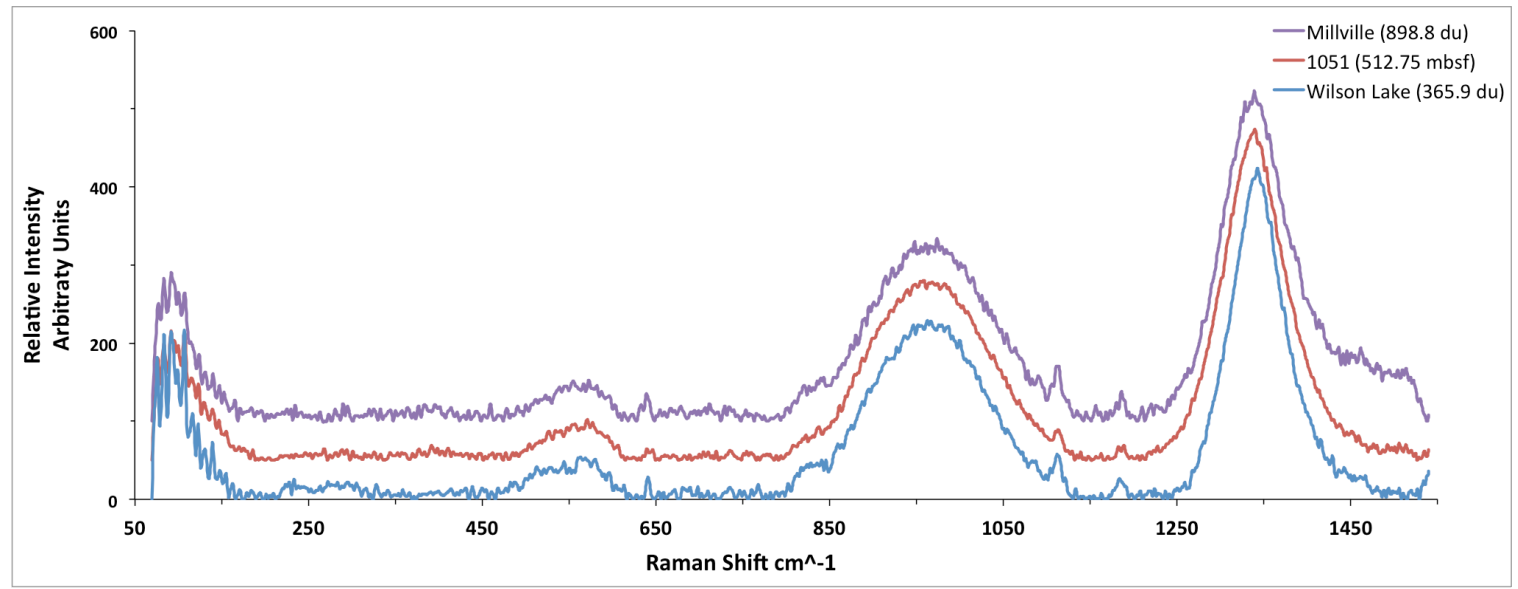

Fig. S17

Micro-laser Raman spectra of representative microtektite matrices. Spectra are collected using a Bruker $532 \mathrm{~nm}$ green laser system at RPI and are background corrected. 


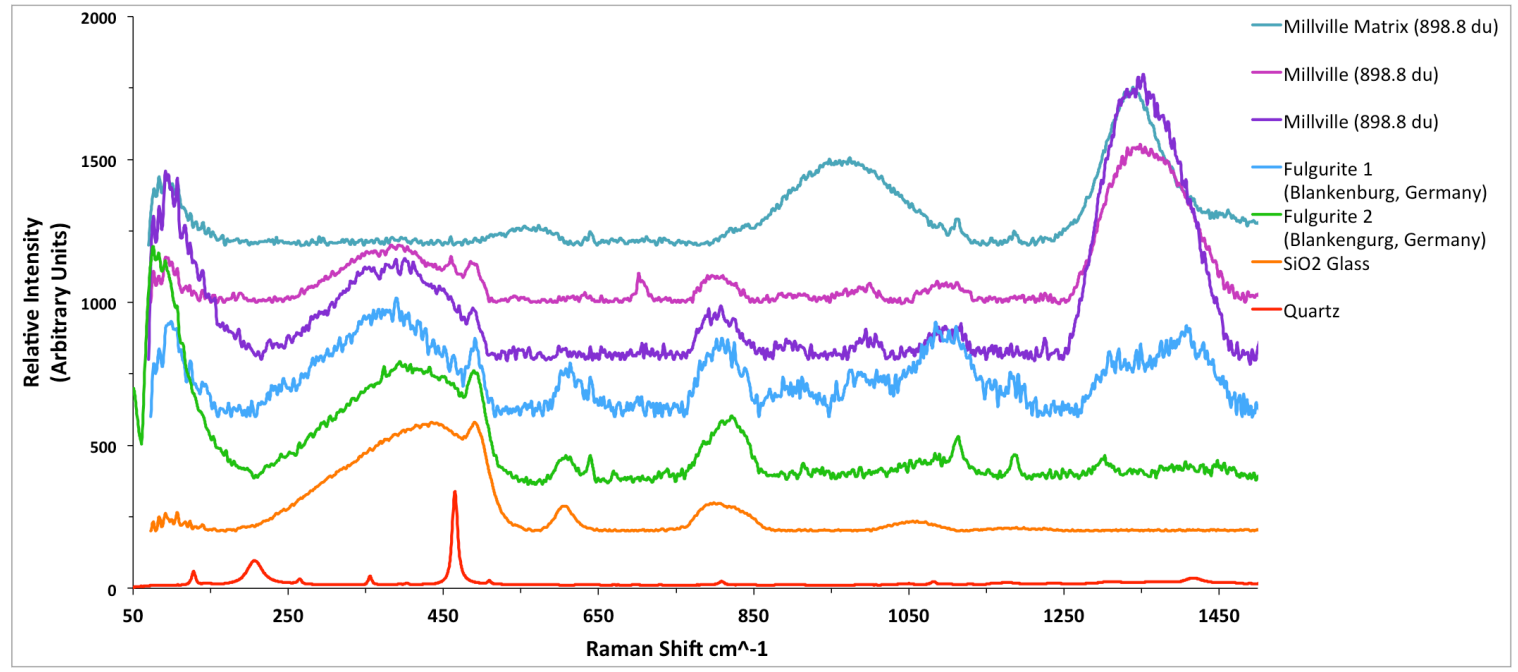

Fig. S18

Background corrected Raman spectra of representative lechatelierite inclusions found in spherules compared to the spherule matrix, lechatelierite inclusions in fulgurite, $\mathrm{SiO}_{2}$ glass, and quartz. Similar peaks in the 1250-1450 wavelength region in the lechatelierite spectrum are effects of the spherule matrix, see Fig. S19 for location of analyses. 


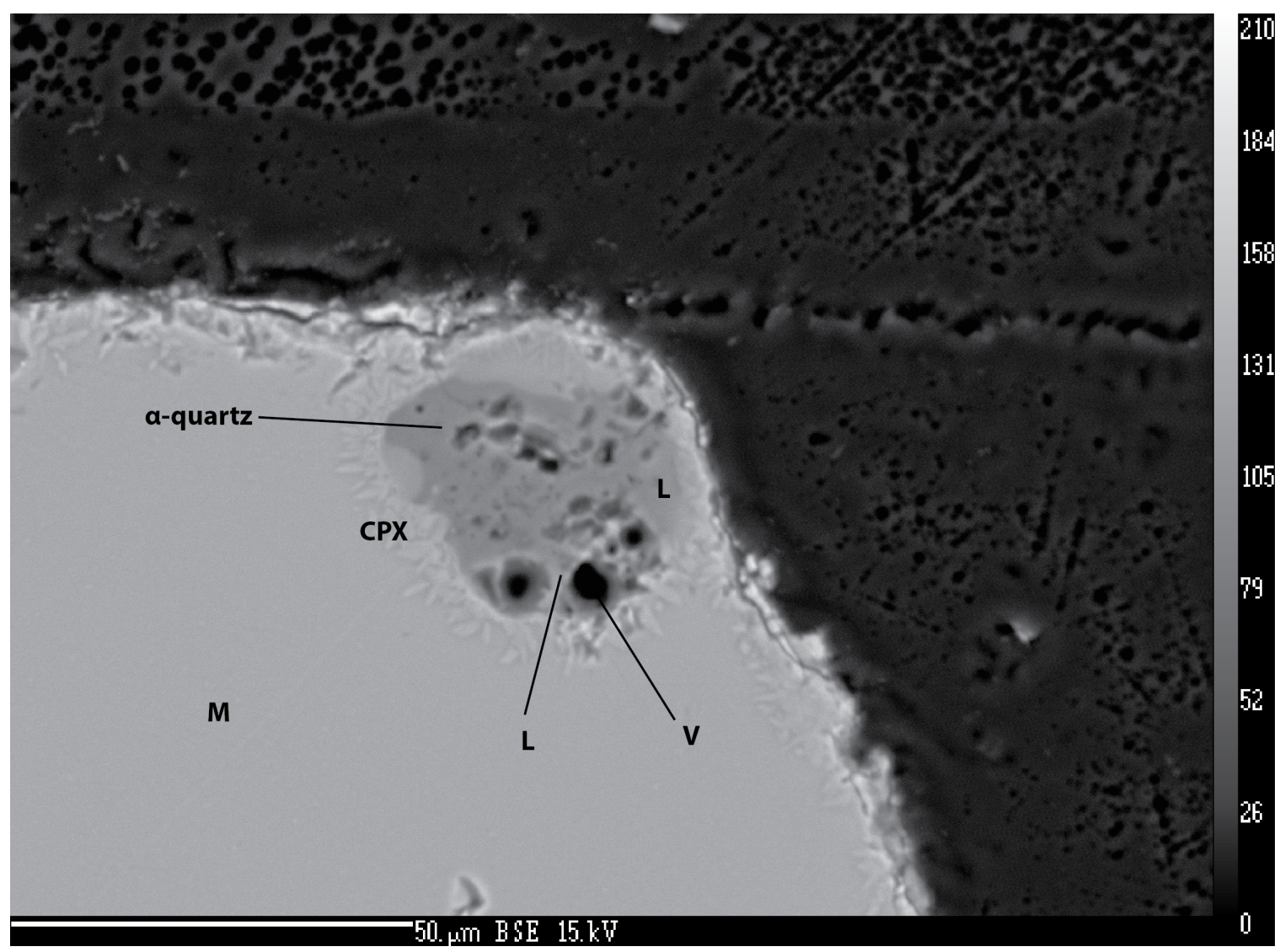

Fig. S19

Electron backscatter image of a polished spherule (Millville $898.8 \mathrm{du}$ ) example of one used to identify the phases by Raman spectroscopy, above. Lechatelierite inclusion (L), matrix (M), clinopyroxene crystalites (cpx), crystalline $\alpha$-quartz ( $\alpha$-quartz), and vesicles (V) are labeled. 


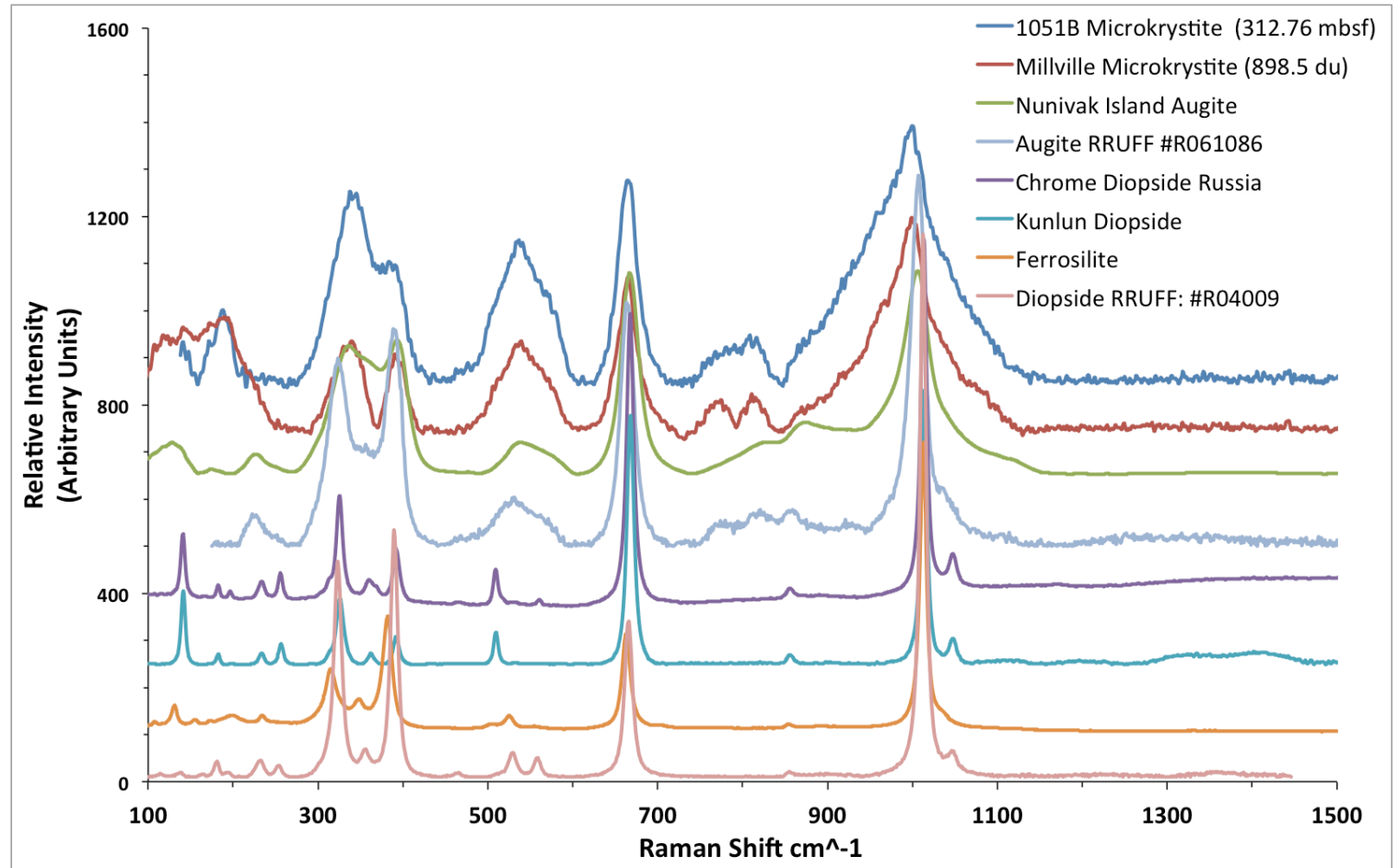

Fig. S20

Raman spectra of representative clinopyroxene crystallites as compared to augite, diopside, and ferrosilite standards. Spectra are background corrected. 

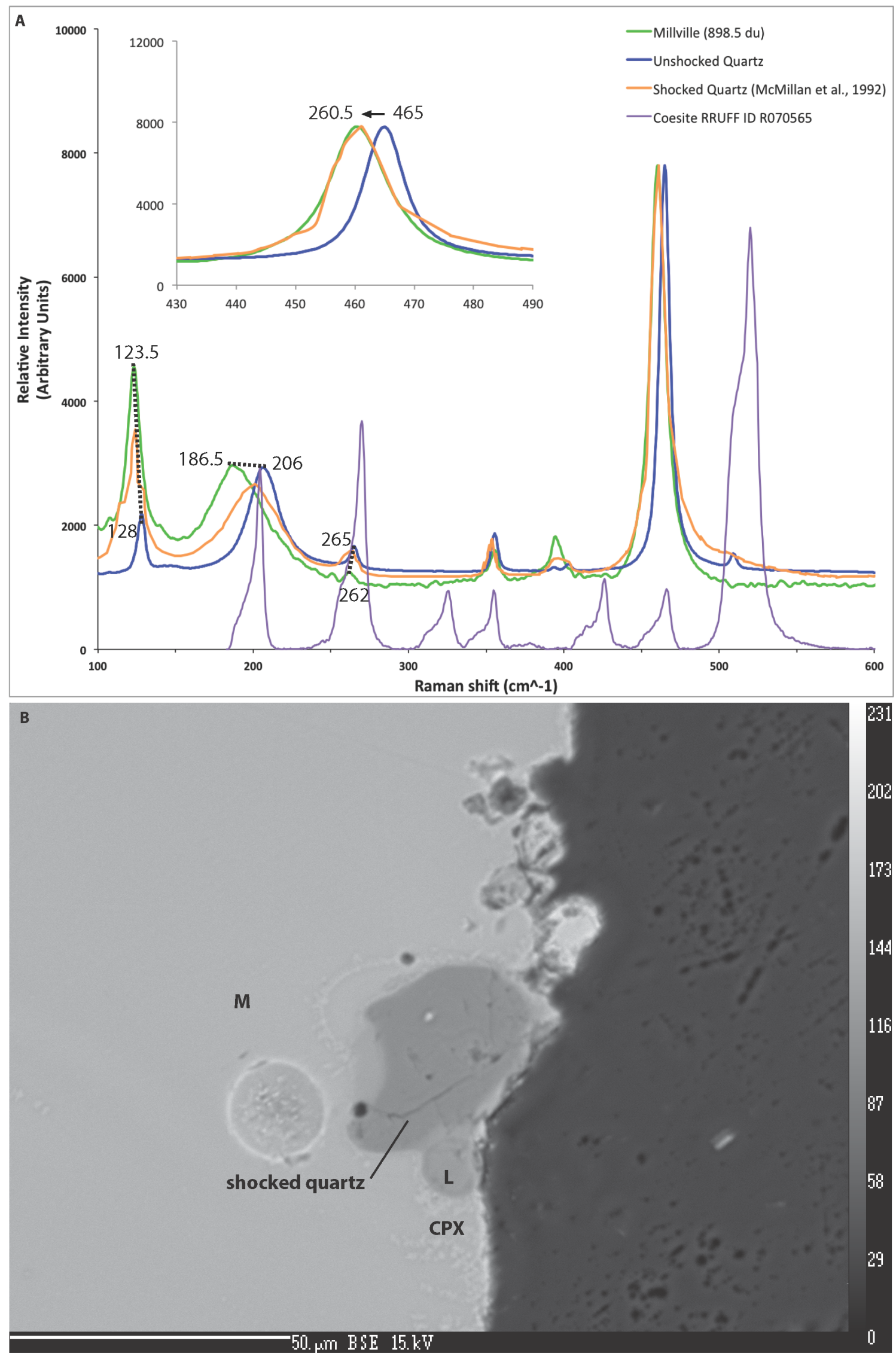


\section{Fig. S21}

A. Background corrected Raman spectrum collected from a polished microkrystite containing crystalline $\alpha$-quartz (Millville $898.5 \mathrm{du}$ ) and an unshocked quartz standard. The black dashed lines note shifts in various vibrational modes between an unshocked quartz grain and the quartz inclusion in the microkrystite. These measurements are compared to the spectra for quartz shocked to peak pressures of $25.8 \mathrm{GPa}(26)$, which are remarkably consistent with those from the Millville inclusion. The inset shows the characteristic 464 to 450 wavenumber vibrational relaxation associated with shocked quartz. Data from McMillan et al (26) were digitized from a paper copy. We also show a RRUFF database spectrum for Coesite for reference. B. is an electron backscatter image of the polished microkrystite containing the crystalline shocked quartz inclusion (Millville $898.5 \mathrm{du}$ ) measured, $\mathrm{M}=$ matrix, $\mathrm{cpx}=$ clinopyroxene microlites, $\mathrm{L}=$ lechatelierite. 


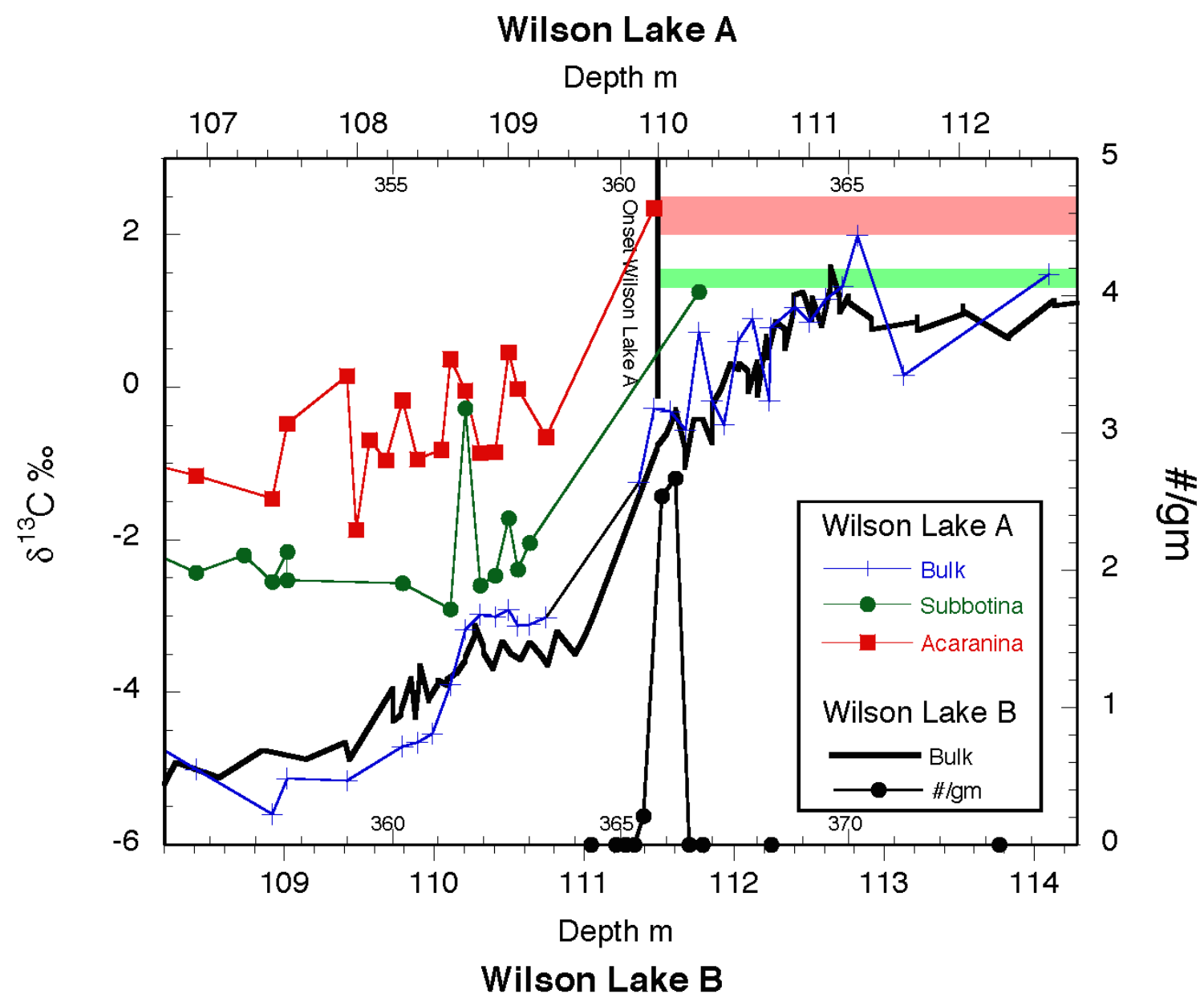

Fig. S22

Correlation of $\delta^{13} \mathrm{C}$ records from Wilson Lake A and B Holes during the onset of the CIE. The vertical black line at $360.9 \mathrm{ft}$ in Wilson Lake A shows the location of the CIE onset determined by Sluijs et al. (50) using a dinoflagellate $\delta^{13} \mathrm{C}$ record. Also shown are two planktonic foraminiferal values from Wilson Lake A $(51)$, which are similar to regional $\delta^{13} \mathrm{C}$ values for each genus in pre-CIE intervals of other sites (red and green shaded boxes) (51). At the bottom of the graph, abundances of spherules found in the BHole are shown, and closely match the Sluijs et al. (50) pick for the P-E boundary based on the onset of the CIE. 


\begin{tabular}{|c|c|c|c|c|c|c|c|}
\hline mbsf & Section & $\begin{array}{c}\text { Sample } \\
\text { Interval } \\
\text { (cm) }\end{array}$ & $\begin{array}{l}\text { Pre-Washed } \\
\text { Weight (g) }\end{array}$ & $\begin{array}{c}\text { Post-Washed } \\
\text { Weight } \\
>63 \mu \mathrm{m} \mathrm{(g)}\end{array}$ & $\begin{array}{c}\text { Post-Washed } \\
\text { Weight 45- } \\
63 \mu \mathrm{m}(\mathrm{g})\end{array}$ & $\begin{array}{l}\text { Spherules } \\
>63 \mu \mathrm{m}\end{array}$ & \#/gram \\
\hline 512.25 & $60-1$ & $135-136$ & 0.23 & 0.01 & 0.01 & 0 & 0 \\
\hline 512.38 & $60-1$ & $148-149$ & 0.69 & 0.08 & 0.02 & 0 & 0 \\
\hline 512.53 & $60-2$ & $13-14$ & 1.32 & 0.03 & 0.01 & 0 & 0 \\
\hline 512.58 & $60-2$ & $18-20$ & 12.18 & 1.83 & & 2 & 0.16 \\
\hline 512.68 & $60-2$ & $28-30$ & 18.66 & 2.89 & & 43 & 2.30 \\
\hline 512.75 & $60-2$ & $36-37-A+B$ & 2.65 & & & 10 & 3.77 \\
\hline 512.88 & $60-2$ & 48-49 & 1.26 & 0.05 & 0.02 & 1 & 0.79 \\
\hline 512.96 & $60-2$ & $56-58$ & 7.73 & 0.82 & & 0 & 0 \\
\hline 513.03 & $60-2$ & $63-65$ & 18.94 & 1.75 & & 0 & 0 \\
\hline 513.12 & $60-2$ & $72-73$ & 1.51 & 0.04 & 0.01 & 0 & 0 \\
\hline 513.13 & $60-2$ & $73-75$ & 20.19 & 1.6 & & 0 & 0 \\
\hline 513.23 & $60-2$ & $83-85$ & 18.99 & 1.14 & & 0 & 0 \\
\hline 513.33 & $60-2$ & $93-95$ & 19.06 & 1.34 & & 0 & 0 \\
\hline
\end{tabular}

Table S1.

Hole 1051B spherule concentrations (\#/gram) and corresponding sample depth. 


\begin{tabular}{|c|c|c|c|c|c|}
\hline Sample (ft) & $\begin{array}{c}\text { Pre- } \\
\text { Washed } \\
\text { Weight (g) }\end{array}$ & $\begin{array}{c}\text { Post- } \\
\text { Washed } \\
\text { Weight } \\
>63 \mu \mathrm{m}(\mathrm{g})\end{array}$ & $\begin{array}{c}\text { Post- } \\
\text { Washed } \\
\text { Weight 45- } \\
63 \mu \mathrm{m} \mathrm{(g)}\end{array}$ & $\begin{array}{c}\text { Spherules } \\
>63 \mu \mathrm{m}\end{array}$ & \#/gram \\
\hline 364.35 & 4.46 & 0.23 & 0.07 & 0 & 0 \\
\hline 364.90 & 5.53 & 0.66 & 0.09 & 0 & 0 \\
\hline 365.10 & 6.26 & 0.63 & 0.11 & 0 & 0 \\
\hline 365.30 & 4.86 & 0.50 & 0.09 & 0 & 0 \\
\hline 365.50 & 4.82 & 0.59 & 0.08 & 1 & 0.21 \\
\hline 365.90 & 10.25 & 2.86 & 0.28 & 26 & 2.54 \\
\hline 366.20 & 2.62 & 0.88 & 0.08 & 7 & 2.67 \\
\hline 366.50 & 3.92 & 1.35 & 0.14 & 0 & 0 \\
\hline 366.80 & 2.89 & 1.23 & 0.05 & 0 & 0 \\
\hline 368.30 & 3.81 & 1.67 & 0.15 & 0 & 0 \\
\hline 373.30 & 5.52 & 2.16 & 0.36 & 0 & 0 \\
\hline
\end{tabular}

Table S2.

Wilson Lake B spherule concentrations (\#/gram) and corresponding sample depth. 


\begin{tabular}{|c|c|c|c|c|c|c|}
\hline Sample (ft) & $\begin{array}{c}\text { Adj. Sample } \\
\text { (ft) }\end{array}$ & $\begin{array}{c}\text { Pre- } \\
\text { Washed } \\
\text { Weight (g) }\end{array}$ & $\begin{array}{c}\text { Post- } \\
\text { Washed } \\
\text { Weight } \\
>63 \mu \mathrm{m}(\mathrm{g})\end{array}$ & $\begin{array}{c}\text { Post- } \\
\text { Washed } \\
\text { Weight 45- } \\
63 \mu \mathrm{m}(\mathrm{g})\end{array}$ & $\begin{array}{c}\text { Spherules } \\
>63 \mu \mathrm{m}\end{array}$ & \#/gram \\
\hline 898.20 & 897.70 & 8.36 & 0.76 & 0.36 & 1 & 0.12 \\
\hline 898.50 & 897.98 & 8 & & & 2 & 0.25 \\
\hline 898.80 & 898.26 & 8.21 & 1.17 & 0.56 & 17 & 2.07 \\
\hline 899.40 & 898.83 & 9 & 2.13 & 0.89 & 0 & 0 \\
\hline 899.60 & 899.01 & 8.36 & 1.47 & 0.46 & 0 & 0 \\
\hline 901.90 & 901.81 & 7.64 & 2.68 & 0.62 & 0 & 0 \\
\hline 903.60 & 903.43 & 7.33 & 3.4 & 0.93 & 0 & 0 \\
\hline
\end{tabular}

Table S3.

Millville spherule concentrations (\#/gram) and corresponding sample depth. 


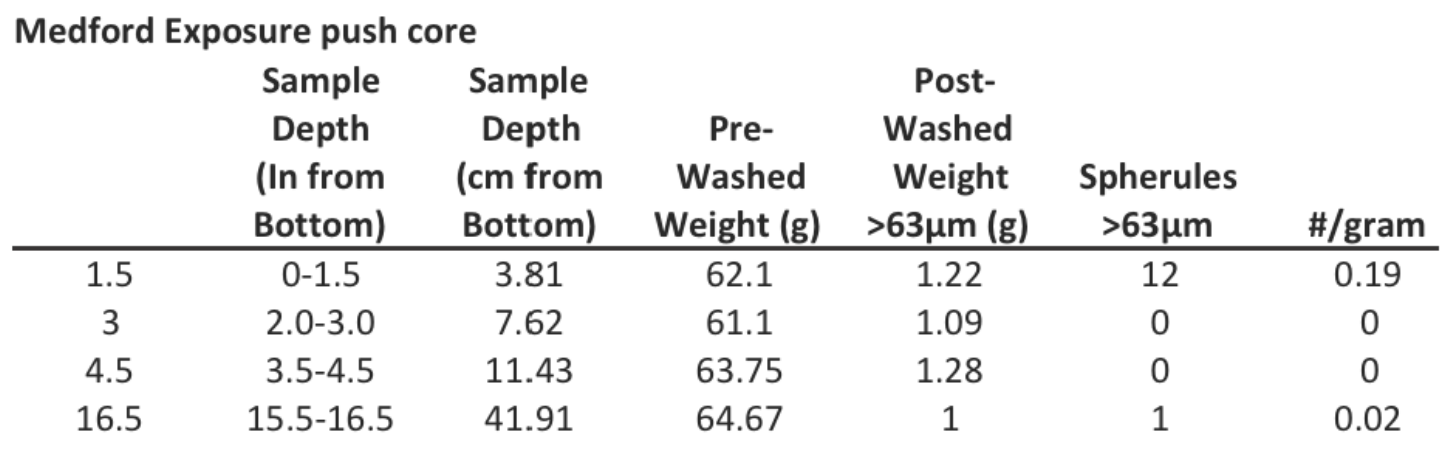

Table S4.

Medford Exposure spherule concentrations (\#/gram) and corresponding sample depth (inches) from a short $(50 \mathrm{~cm})$ push-core taken at the exposure. Sample depths measured from the bottom of the core. 


\begin{tabular}{|c|c|c|}
\hline \multicolumn{3}{|c|}{$\begin{array}{c}\text { Integrated Molar } \\
\text { Absorption Coefficient }\end{array}$} \\
\hline Sample & $\mathrm{L} /\left(\mathrm{mol}^{*} \mathrm{~cm}^{\wedge} 2\right)^{*}$ & Weight $\% \mathrm{H}_{2} \mathrm{O} * *$ \\
\hline Medford $3.81 \mathrm{~cm}$ (Microtektite) & $32000 \pm 3200$ & $0.0228 \pm 0.00173$ \\
\hline Wilson Lake B 365.9 du A (Microtektite) & $32000 \pm 3200$ & $0.0234 \pm 0.000782$ \\
\hline Wilson Lake B 365.9 du B (Microkrystite) & $32000 \pm 3200$ & $0.00988 \pm 0.00253$ \\
\hline
\end{tabular}

\section{Table S5.}

Weight $\% \mathrm{H}_{2} \mathrm{O}$ content determined by FTIR from polished sections of spherules. 


\begin{tabular}{|c|c|c|c|c|c|c|c|c|}
\hline Microkrystites: & $\mathrm{SiO}_{2}$ & $\mathrm{Al}_{2} \mathrm{O}_{3}$ & Feo & Mgo & $\mathrm{K}_{2} \mathrm{O}$ & $\mathrm{CaO}$ & $\mathrm{TiO}_{2}$ & $\mathrm{Na}_{2} \mathrm{O}$ \\
\hline MV 898.5 AM-2 SPHERE POLISHED DARK & 49.98 & 21.89 & 3.94 & 1.71 & 0.34 & 21.04 & 0.64 & 0.09 \\
\hline 1051 AL-5 SPHERE POLISHED DARK & 48.43 & 17.03 & 6.16 & 0.37 & 0.56 & 25.08 & 1.53 & 0.08 \\
\hline 1051 AL-2 SPHERE POLISHED GREY & 46.74 & 16.31 & 8.32 & 0.39 & 0.38 & 25.11 & 1.85 & 0.05 \\
\hline MD B2 0-1.5 AH-1 SPHERE & 44.37 & 15.87 & 10.20 & 3.07 & 0.42 & 24.00 & 1.42 & 0.00 \\
\hline MV 898.8 AO-1 SPHERE POLISHED & 43.27 & 17.56 & 6.77 & 3.47 & 0.35 & 25.76 & 1.86 & 0.19 \\
\hline WL 365.9 AK-1 SPHERE & 43.14 & 10.81 & 10.05 & 3.29 & 0.70 & 27.51 & 2.59 & 0.83 \\
\hline 1051 AL-3 SPHERE POLISHED BACKGROUND & 42.96 & 14.71 & 11.22 & 0.83 & 0.50 & 27.71 & 1.69 & 0.00 \\
\hline MD B2 0-1.5 AE-1 SPHERE & 41.97 & 14.80 & 10.09 & 3.08 & 0.49 & 27.19 & 1.50 & 0.05 \\
\hline WL 365.5 BV-1 POLISHED SPHERE & 41.68 & 15.24 & 8.46 & 3.25 & 0.38 & 27.87 & 1.65 & 0.69 \\
\hline 1051 AL-4 SPHERE POLISHED CRYSTALS & 40.15 & 13.04 & 12.92 & 4.39 & 0.16 & 27.21 & 1.45 & 0.00 \\
\hline 1051 AL-6 SPHERE POLISHED LIGHT & 39.62 & 12.99 & 14.19 & 4.29 & 0.09 & 26.41 & 1.63 & 0.00 \\
\hline MV 898.8 AM-1 SPHERE POLISHED & 39.33 & 16.15 & 6.95 & 4.20 & 0.42 & 30.08 & 1.56 & 0.21 \\
\hline 1051 AL-1 SPHERE POLISHED & 39.20 & 12.82 & 13.81 & 4.35 & 0.14 & 27.36 & 1.74 & 0.00 \\
\hline WL 365.9 AB-1 SPHERE & 37.51 & 12.25 & 12.49 & 4.43 & 0.92 & 30.07 & 1.39 & 0.00 \\
\hline 1051 AF-1 SPHERE & 37.42 & 17.42 & 16.95 & 4.34 & 1.58 & 17.94 & 1.76 & 0.98 \\
\hline MD B2 0-1.5 AG-1 SPHERE & 36.95 & 16.72 & 7.99 & 4.21 & 0.38 & 30.90 & 1.58 & 0.26 \\
\hline WL 365.5 BW-1 POLISHED SPHERE & 35.78 & 15.82 & 12.90 & 5.15 & 0.13 & 27.28 & 1.98 & 0.00 \\
\hline \multicolumn{9}{|l|}{ Microtektites: } \\
\hline MV 898.8 AQ-1 POLISHED SPHERE & 49.02 & 16.57 & 11.53 & 2.47 & 0.40 & 18.11 & 1.30 & 0.00 \\
\hline WL 365.9 AP-4 SPHERE POLISHED & 47.22 & 20.10 & 5.90 & 2.52 & 0.21 & 21.82 & 1.34 & 0.07 \\
\hline WL 365.9 Al-1 SPHERE & 46.70 & 18.32 & 11.40 & 3.24 & 0.32 & 16.95 & 1.30 & 0.41 \\
\hline 1051 AK-1 SPHERE POLISHED & 45.77 & 15.32 & 9.64 & 2.83 & 0.39 & 23.93 & 1.42 & 0.05 \\
\hline 1051 AA-1 SPHERE & 45.72 & 16.54 & 9.49 & 3.87 & 0.43 & 21.27 & 1.45 & 0.46 \\
\hline WL 365.9 AP-1 SPHERE POLISHED & 45.67 & 17.62 & 9.18 & 2.79 & 0.43 & 21.61 & 1.50 & 0.25 \\
\hline MV 898.8 AK-1 SPHERE POLISHED & 45.57 & 14.81 & 9.10 & 2.69 & 0.43 & 25.28 & 1.38 & 0.00 \\
\hline MV 898.8 AH-1 SPHERE & 45.06 & 15.25 & 11.88 & 2.43 & 0.65 & 21.82 & 1.35 & 0.24 \\
\hline WL 365.9 AO-1 GREEN SPHERE POLISHED & 43.90 & 16.15 & 9.04 & 3.12 & 0.39 & 24.43 & 2.03 & 0.15 \\
\hline MV 898.8 AD-2 ROTATIONAL FORM & 43.78 & 15.17 & 11.41 & 3.23 & 0.41 & 23.04 & 1.88 & 0.17 \\
\hline 1051 AJ-1 SPHERE POLISHED & 43.63 & 16.27 & 6.30 & 3.16 & 0.32 & 27.34 & 1.99 & 0.00 \\
\hline MV 898.8 AH-2 SPHERE & 42.81 & 14.49 & 12.17 & 2.22 & 0.77 & 24.38 & 1.86 & 0.14 \\
\hline WL 365.9 AJ-1 SPHERE & 42.69 & 14.79 & 9.76 & 2.77 & 0.46 & 26.17 & 1.57 & 0.20 \\
\hline 1051 Al-1 SPHERE POLISHED & 42.67 & 16.71 & 8.20 & 3.20 & 0.40 & 26.20 & 1.78 & 0.06 \\
\hline 1051 AH-1 SPHERE & 42.54 & 14.11 & 8.71 & 3.17 & 0.44 & 28.15 & 1.94 & 0.20 \\
\hline MV 898.8 AD-1 ROTATIONAL FORM & 41.96 & 14.56 & 12.49 & 3.02 & 0.39 & 23.97 & 1.97 & 0.06 \\
\hline 1051 AG-1 SPHERE & 41.65 & 15.44 & 7.98 & 3.73 & 0.57 & 27.46 & 1.99 & 0.09 \\
\hline MV 898.5 AN-1 ROTATIONAL FORM POLISHED & 41.47 & 15.46 & 9.41 & 3.61 & 0.43 & 26.63 & 1.63 & 0.36 \\
\hline WL 366.2 AA-1 ROTATIONAL FORM & 40.82 & 15.80 & 11.18 & 3.18 & 0.30 & 25.26 & 1.72 & 0.10 \\
\hline WL 365.9 AA-1 SPHERE & 40.67 & 15.18 & 10.37 & 3.32 & 0.43 & 26.75 & 2.08 & 0.02 \\
\hline MV 898.8 AI SPHERE POLISHED & 40.28 & 15.68 & 8.95 & 3.29 & 0.33 & 28.50 & 2.13 & 0.12 \\
\hline 1051 AC-1 SPHERE & 40.12 & 16.00 & 8.64 & 4.71 & 0.33 & 26.66 & 1.77 & 0.36 \\
\hline MD B2 0-1.5 AF-1 SPHERE & 39.95 & 14.64 & 9.71 & 3.33 & 0.55 & 28.80 & 1.75 & 0.27 \\
\hline MV 898.8 AL-1 SPHERE POLISHED & 39.76 & 15.64 & 7.44 & 3.74 & 0.38 & 29.94 & 1.93 & 0.07 \\
\hline MV 898.8 AP-1 POLISHED SPHERE & 39.44 & 15.68 & 9.80 & 3.36 & 0.30 & 28.05 & 2.14 & 0.08 \\
\hline 1051 AB-1 SPHERE & 39.36 & 16.22 & 7.58 & 4.31 & 0.41 & 28.67 & 2.00 & 0.33 \\
\hline MV 898.8 AJ-1 SPHERE POLISHED & 39.01 & 13.09 & 20.28 & 2.70 & 0.31 & 22.49 & 1.43 & 0.00 \\
\hline WL 365.9 AQ-1 SPHERE POLISHED & 38.65 & 15.71 & 8.68 & 3.79 & 0.30 & 29.45 & 1.95 & 0.10 \\
\hline 1051 AE-1 SPHERE & 38.45 & 15.17 & 7.72 & 4.64 & 0.39 & 29.57 & 1.72 & 1.32 \\
\hline MV 898.8 AN-3 SPHERE POLISHED GREY SPOT & 38.41 & 14.22 & 7.47 & 3.12 & 1.06 & 32.23 & 1.84 & 0.14 \\
\hline WL 365.9 AH-1 SPHERE & 38.40 & 15.80 & 9.12 & 3.94 & 0.28 & 29.64 & 1.64 & 0.08 \\
\hline MV 898.8 AB-2 SPHERE & 38.08 & 15.27 & 11.70 & 3.87 & 0.37 & 28.28 & 1.60 & 0.27 \\
\hline MV 898.8 AN-1 SPHERE POLISHED & 37.57 & 15.07 & 7.91 & 3.65 & 0.34 & 31.92 & 2.28 & 0.21 \\
\hline WL 366.2 AC-1 SPHERE & 37.55 & 14.92 & 9.44 & 3.88 & 0.45 & 29.77 & 2.18 & 0.29 \\
\hline MV 898.8 AG-1 SPHERE & 36.96 & 13.65 & 17.52 & 3.35 & 0.34 & 25.46 & 1.37 & 0.00 \\
\hline 1051 AD-1 DARK SPHERE & 36.69 & 15.11 & 18.97 & 3.94 & 0.35 & 20.98 & 1.55 & 0.41 \\
\hline MV 898.8 AC-1 SPHERE & 36.54 & 14.33 & 11.65 & 3.54 & 0.61 & 30.46 & 1.76 & 0.22 \\
\hline MV 898.8 AC-2 SPHERE & 36.54 & 14.33 & 11.65 & 3.54 & 0.61 & 30.46 & 1.76 & 0.22 \\
\hline MV 898.8 AB-1 SPHERE & 36.33 & 14.00 & 12.88 & 3.24 & 0.41 & 31.04 & 1.77 & 0.00 \\
\hline WL 365.9 AR-1 SPHERE POLISHED & 35.96 & 15.09 & 8.62 & 3.51 & 0.32 & 33.13 & 2.28 & 0.01 \\
\hline MD B2 0-1.5 AD-1 SPHERE & 35.22 & 15.25 & 9.03 & 3.98 & 0.32 & 33.08 & 1.83 & 0.09 \\
\hline MD B2 0-1.5 AC-1 ROTATIONAL FORM & 34.49 & 13.21 & 14.50 & 2.92 & 0.49 & 31.53 & 1.73 & 0.00 \\
\hline WL 365.9 AL-1 SPHERE & 33.45 & 13.46 & 15.83 & 2.76 & 0.37 & 28.94 & 1.91 & 0.00 \\
\hline WL 365.5 BU-1 SPHERE POLISHED & 32.91 & 17.22 & 9.49 & 3.51 & 0.62 & 31.93 & 2.68 & 0.40 \\
\hline
\end{tabular}

Table S6.

Major oxide chemistries determined by EDS of the matrix from either grain mount or polished spherules from sites 1051 (512.75 mbsf), Millville (MV), Wilson Lake B (WL), and Medford (MD). Spherules are separated by microtektites and microkrystites and sorted by $\mathrm{SiO}_{2}$ content. 


\section{References}

1. B. P. Glass, Microtektite surface sculpturing. Geol. Soc. Am. Bull. 85, 1305-1314 (1974). doi:10.1130/0016-7606(1974)85<1305:MSS>2.0.CO;2

2. B. Glass, Tektites and microtektites: Key facts and inferences. Tectonophysics 171, 393-404 (1990). doi:10.1016/0040-1951(90)90112-L

3. B. Glass, C. A. Burns, in Lunar and Planetary Science Conference Proceedings (1988), vol. 18, pp. 455-458.

4. D. Stöffler, Glasses formed by hypervelocity impact. J. Non-Cryst. Solids 67, 465-502 (1984). doi:10.1016/0022-3093(84)90171-6

5. D. Stöffler, F. Langenhorst, Shock metamorphism of quartz in nature and experiment: I. Basic observation and theory. Meteoritics 29, 155-181 (1994). doi:10.1111/j.19455100.1994.tb00670.x

6. B. P. Glass, B. M. Simonson, Distal Impact Ejecta Layers: A Record of Large Impacts in Sedimentary Deposits (Springer Science \& Business Media, 2012).

7. M.-P. Aubry, K. Ouda, C. Dupuis, W. A. Berggren, J. A. van Couvering, Working Group on the Paleocene/Eocene Boundary, The Global Standard Stratotype-section and Point (GSSP) for the base of the Eocene Series in the Dababiya section (Egypt). Episodes 30, 271-286 (2007).

8. P. J. Sugarman et al., in Proceedings of the Ocean Drilling Program, Initial Reports, K. G. Miller, P. J. Sugarman, J. V. Browning, Eds. (Ocean Drilling Program, College Station, TX, 2005)

9. R. Norris, D. Kroon, A. Klaus, in Proceedings of the Ocean Drilling Program, Initial Reports. (1998), vol. 171, pp. 1-749.

10. J. D. Wright, M. F. Schaller, Evidence for a rapid release of carbon at the Paleocene-Eocene thermal maximum. Proc. Natl. Acad. Sci. U.S.A. 110, 15908-15913 (2013). Medline doi:10.1073/pnas.1309188110

11. M. E. Katz, D. K. Pak, G. R. Dickens, K. G. Miller, The source and fate of massive carbon input during the latest Paleocene thermal maximum. Science 286, 1531-1533 (1999). Medline doi:10.1126/science.286.5444.1531

12. All primary data are available as supplementary materials on Science Online.

13. S. Liu, B. Glass, F. T. Kyte, S. M. Bohaty, The late Eocene clinopyroxene-bearing spherule layer: New sites, nature of the strewn field, Ir data, and discovery of coesite and shocked quartz. Geolog. Soc. Am. Spec. Pap. 452, 37-70 (2009).

14. C. W. Poag, The Chesapeake Bay bolide impact: A convulsive event in Atlantic Coastal Plain evolution. Sediment. Geol. 108, 45-90 (1997). doi:10.1016/S0037-0738(96)00048$\underline{6}$

15. F. Langenhorst, Characteristics of shocked quartz in late Eocene impact ejecta from Massignano (Ancona, Italy): Clues to shock conditions and source crater. Geology 24, 487-490 (1996). doi:10.1130/0091-7613(1996)024<0487:COSQIL>2.3.CO;2 
16. B. P. Glass, S. Liu, A. Montanari, Impact ejecta in upper Eocene deposits at Massignano, Italy. Meteorit. Planet. Sci. 39, 589-597 (2004). doi:10.1111/j.1945-5100.2004.tb00921.x

17. B. P. Glass, Upper Eocene impact ejecta spherule layers in marine sediments. Chemie Erde Geochem. 62, 173-196 (2002). doi:10.1078/0009-2819-00017

18. B. P. Glass, H. Huber, C. Koeberl, Geochemistry of Cenozoic microtektites and clinopyroxene-bearing spherules. Geochim. Cosmochim. Acta 68, 3971-4006 (2004). doi:10.1016/j.gca.2004.02.026

19. C. Koeberl, The geochemistry of tektites: An overview. Tectonophysics 171, 405-422 (1990). doi:10.1016/0040-1951(90)90113-M

20. C. Koeberl, Tektite origin by hypervelocity asteroidal or cometary impact: Target rocks, source craters, and mechanisms. Geolog. Soc. Am. Spec. Pap. 293, 133-152 (1992).

21. C. Koeberl, A. Beran, in Lunar and Planetary Science Conference Proceedings (1988), vol. 18, pp. 403-408.

22. A. Beran, C. Koeberl, Water in tektites and impact glasses by Fourier-transformed infrared spectrometry. Meteorit. Planet. Sci. 32, 211-216 (1997). doi:10.1111/j.1945$\underline{5100.1997 . t b 01260 . x}$

23. H. Melosh, N. Artemieva, How does tektite glass lose its water? Lunar Planet. Sci. XXXV, 1723 (2004).

24. D. Parkin, R. Sullivan, J. Andrews, Further studies on cosmic spherules from deep-sea sediments. Philosoph. Trans. R. Soc. Lond. A: Math. Phys. Eng. Sci. 297, 495-518 (1980). doi:10.1098/rsta.1980.0227

25. D. Stöffler, G. Ryder, B. A. Ivanov, N. A. Artemieva, M. J. Cintala, R. A. F. Grieve, Cratering history and lunar chronology. Rev. Mineral. Geochem. 60, 519-596 (2006). doi:10.2138/rmg.2006.60.05

26. A. J. Gratz, D. K. Fisler, B. F. Bohor, Distinguishing shocked from tectonically deformed quartz by the use of the SEM and chemical etching. Earth Planet. Sci. Lett. 142, 513-521 (1996). doi:10.1016/0012-821X(96)00099-4

27. P. F. McMillan, G. H. Wolf, P. Lambert, A Raman spectroscopic study of shocked single crystalline quartz. Phys. Chem. Miner. 19, 71-79 (1992). doi:10.1007/BF00198604

28. H. Vonhof, J. Smit, Late Eocene microkrystites and microtektites at Maud Rise (Ocean Drilling Project Hole 689B; Southern Ocean) suggest a global extension of the approximately 35.5 Ma Pacific impact ejecta strewn field. Meteorit. Planet. Sci. 34, 747755 (1999). doi:10.1111/j.1945-5100.1999.tb01387.x

29. C. John, B. P. Glass, Clinopyroxene-bearing glass spherules Associated with North American microtektites. Geology 2, 599-602 (1974). doi:10.1130/00917613(1974)2<599:CGSAWN>2.0.CO;2

30. B. Glass, C. A. Burns, J. R. Crosbie, D. L. DuBois, Late Eocene North American microtektites and clinopyroxene-bearing spherules. J. Geophys. Res. Solid Earth 90 (S01), 175-196 (1985). doi:10.1029/JB090iS01p00175 
31. S. Liu, D. Papanastassiou, H. Ngo, B. Glass, Sr and Nd analyses of upper Eocene spherules and their implications for target rocks. Meteorit. Planet. Sci. 41, 705-714 (2006). doi:10.1111/j.1945-5100.2006.tb00986.x

32. H. D. Bermúdez, J. García, W. Stinnesbeck, G. Keller, J. V. Rodríguez, M. Hanel, J. Hopp, W. H. Schwarz, M. Trieloff, L. Bolívar, F. J. Vega, The Cretaceous-Palaeogene boundary at Gorgonilla Island, Colombia, South America. Terra Nova 28, 83-90 (2016). doi:10.1111/ter.12196

33. S. L. D'Hondt, G. Keller, R. F. Stallard, Major element compositional variation within and between different late Eocene microtektite strewnfields. Meteoritics 22, 61-79 (1987). doi:10.1111/j.1945-5100.1987.tb00884.X

34. R. K. Olsson, K. G. Miller, J. V. Browning, D. Habib, P. J. Sugarman, Ejecta layer at the Cretaceous-Tertiary boundary, Bass River, New Jersey (Ocean Drilling Program Leg 174AX). Geology 25, 759-762 (1997). doi:10.1130/00917613(1997)025<0759:ELATCT>2.3.CO;2

35. W. Alvarez, J. Smit, W. Lowrie, F. Asaro, S. V. Margolis, P. Claeys, M. Kastner, A. R. Hildebrand, Proximal impact deposits at the Cretaceous-Tertiary boundary in the Gulf of Mexico: A restudy of DSDP Leg 77 Sites 536 and 540. Geology 20, 697-700 (1992). Medline doi:10.1130/0091-7613(1992)020<0697:PIDATC $>2.3 . C O ; 2$

36. A. D. Harris, K. G. Miller, J. V. Browning, P. J. Sugarman, R. K. Olsson, B. S. Cramer, J. D. Wright, Integrated stratigraphic studies of Paleocene \& lowermost Eocene sequences, New Jersey Coastal Plain: Evidence for glacioeustatic control. Paleoceanography 25, PA3211 (2010). doi:10.1029/2009PA001800

37. S. Bains, R. M. Corfield, R. D. Norris, Mechanisms of climate warming at the end of the paleocene. Science 285, 724-727 (1999). Medline doi:10.1126/science.285.5428.724

38. B. Schmitz, F. Asaro, E. Molina, S. Monechi, K. von Salis, R. P. Speijer, High-resolution iridium, $\delta 13 \mathrm{C}, \delta 18 \mathrm{O}$, foraminifera and nannofossil profiles across the latest Paleocene benthic extinction event at Zumaya, Spain. Palaeogeogr. Palaeoclimatol. Palaeoecol. 133, 49-68 (1997). doi:10.1016/S0031-0182(97)00024-2

39. B. Schmitz, B. Peucker-Ehrenbrink, C. Heilmann-Clausen, G. Åberg, F. Asaro, C.-T. A. Lee, Basaltic explosive volcanism, but no comet impact, at the Paleocene-Eocene boundary: High-resolution chemical and isotopic records from Egypt, Spain and Denmark. Earth Planet. Sci. Lett. 225, 1-17 (2004). doi:10.1016/j.epsl.2004.06.017

40. T. Dolenec, J. Pavšič, S. Lojen, Ir anomalies and other elemental markers near the Palaeocene-Eocene boundary in a flysch sequence from the Western Tethys (Slovenia). Terra Nova 12, 199-204 (2000). doi:10.1046/j.1365-3121.2000.00292.x

41. A. Montanari, F. Asaro, H. V. Michel, J. P. Kennett, Iridium anomalies of late Eocene age at Massignano (Italy), and ODP site 689B (Maud Rise, Antarctic). Palaios 8, 420-437 (1993). doi:10.2307/3515017

42. C. Lombardi, Lithostratigraphy and Clay Mineralogy of Paleocene-Eocene Thermal Maximum Sediments from Wilson Lake, NJ (Rutgers University, 2013). 
43. J. P. Kennett, L. D. Stott, Abrupt deep-sea warming, palaeoceanographic changes and benthic extinctions at the end of the Palaeocene. Nature 353, 225-229 (1991).

doi: $10.1038 / 353225 \mathrm{a} 0$

44. Y. Cui, L. R. Kump, A. J. Ridgwell, A. J. Charles, C. K. Junium, A. F. Diefendorf, K. H. Freeman, N. M. Urban, I. C. Harding, Slow release of fossil carbon during the Palaeocene-Eocene Thermal Maximum. Nat. Geosci. 4, 481-485 (2011). doi:10.1038/ngeo1179

45. P. L. Koch, J. C. Zachos, P. D. Gingerich, Correlation between isotope records in marine and continental carbon reservoirs near the Palaeocene/Eocene boundary. Nature 358, 319322 (1992). doi:10.1038/358319a0

46. G. J. Bowen, B. J. Maibauer, M. J. Kraus, U. Röhl, T. Westerhold, A. Steimke, P. D. Gingerich, S. L. Wing, W. C. Clyde, Two massive, rapid releases of carbon during the onset of the Palaeocene-Eocene thermal maximum. Nat. Geosci. 8, 44-47 (2015). doi:10.1038/ngeo2316

47. A. Sluijs, G. R. Dickens, Assessing offsets between the $\delta 13 \mathrm{C}$ of sedimentary components and the global exogenic carbon pool across early Paleogene carbon cycle perturbations. Global Biogeochem. Cycles 26, GB4005 (2012).

48. J. C. Zachos, S. Schouten, S. Bohaty, T. Quattlebaum, A. Sluijs, H. Brinkhuis, S. J. Gibbs, T. J. Bralower, Extreme warming of mid-latitude coastal ocean during the PaleoceneEocene Thermal Maximum: Inferences from TEX86 and isotope data. Geology 34, 737740 (2006). doi:10.1130/G22522.1

49. T. Gibson, L. Bybell, D. Mason, Stratigraphic and climatic implications of clay mineral changes around the Paleocene/Eocene boundary of the northeastern US margin. Sediment. Geol. 134, 65-92 (2000). doi:10.1016/S0037-0738(00)00014-2 